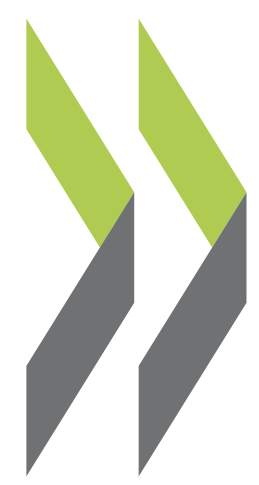

OECD Science, Technology and Industry Working Papers 2005/04

\title{
Status and Overview of Official ICT Indicators for China
} Masahiro Katsuno 
Organisation de Coopération et de Développement Economiques

DIRECTORATE FOR SCIENCE, TECHNOLOGY AND INDUSTRY

STATUS AND OVERVIEW OF OFFICIAL ICT INDICATORS FOR CHINA

STI WORKING PAPER 2005/4

Statistical Analysis of Science, Technology and Industry

Masahiro Katsuno 


\section{STI Working Paper Series}

The Working Paper series of the OECD Directorate for Science, Technology and Industry is designed to make available to a wider readership selected studies prepared by staff in the Directorate or by outside consultants working on OECD projects. The papers included in the series cover a broad range of issues, of both a technical and policy-analytical nature, in the areas of work of the DSTI. The Working Papers are generally available only in their original language - English or French - with a summary in the other.

Comments on the papers are invited, and should be sent to the Directorate for Science, Technology and Industry, OECD, 2 rue André-Pascal, 75775 Paris Cedex 16, France.

The opinions expressed in these papers are the sole responsibility of the author(s) and do not necessarily reflect those of the OECD or of the governments of its member countries.

\section{http://www.oecd.org/sti/working-papers}


DSTI/DOC(2005)4

\title{
STATUS AND OVERVIEW OF OFFICIAL ICT INDICATORS FOR CHINA
}

\author{
Masahiro Katsuno*
}

\begin{abstract}
This paper examines the state of official ICT statistics in China and tries to assess ICT development in China from the currently available information. This can be seen as a first order stocktaking. The aim would be to move to a situation where data can be collected more systematically from China so as to compare them internationally.

Compared with OECD countries, statistics play a unique role in China, as they are an important tool for showing the progress made towards reaching the quantitative goals set in each Five-Year Plan. The provision of statistical data by various government bodies is therefore quite comprehensive, but because of the objective of these statistics, the information is often not or only partially comparable internationally. Most data from non-official sources are based on official statistics. The Chinese government recently passed legislation which restricts the collection of statistical data by foreign bodies, be they private or governmental. Therefore, the availability of other (non-official) statistical information is quite limited. An important barrier in collating economy-wide, consistent indicators is the vertical structure of the Chinese government, which limits the flow of information between the various ministries and with other institutions that are responsible for data collection. For these reasons, it is difficult to compile a complete set of indicators to compare China's ICT development with other countries. For example, this paper does not contain any indicators of ICT usage by businesses.
\end{abstract}

Nevertheless, from the available information, a number of tentative conclusions can be drawn.

- China is rapidly expanding its production of various types of ICT goods. Trade in ICT goods (both imports and exports) has gone up from just over 12\% of total trade in 1996 to more than $27 \%$ in 2003. China is quickly becoming a major assembly line for ICT goods production. In 2003 , more than $60 \%$ of imports of ICT goods consisted of electronic components, while almost four-fifths of exports of ICT goods were made up of computer, telecommunications, audio and video equipment. Wages in the ICT services sector are very high compared to that of other sectors, and stood at more than three times the national average in 2002.

- Telephone subscriptions are increasing at a fast rate, with mobile phone subscribers overtaking fixed line subscribers in October 2003. Data on the penetration of major durable goods in households show a huge gap between urban and rural households. The regional divide in PC ownership is improving, as the region with the lowest penetration rate in 2002 has a penetration level comparable to that of the fourth province in 1998.

- The geographical distribution of Chinese domain names shows a concentration in the municipalities of Beijing and Shanghai and the Eastern Coastal region of Guangdong, which together had a share of about $60 \%$ until 2002, dropping to under $50 \%$ in 2003 . In terms of

* Manager, International Program, Research Institute of Economy, Trade and Industry (RIETI), Tokyo, Japan; e-mail: katsuno-masahiro@rieti.go.jp. This paper was drafted when the author was an independent consultant. The opinions expressed in this paper are those of the author and do not necessarily reflect those of the OECD or any of its member countries. 
Internet users, there is a trend toward resolving the regional digital divide, with a decrease in the share of Internet users in the municipalities of Beijing and Shanghai as well as the Eastern Coastal province of Guangdong, with an increase in the share of the Western Region.

- About $40 \%$ of Internet users are female, and the population belonging to the age segment under 35 has a share of over $80 \%$ of Internet users, down from almost $90 \%$ in December 1998. The education profile indicates that there is a rapid increase in the share of people with a lower education profile. There has also been a rapid increase in the share of people belonging to lower income profiles.

- The main primary objective of using the Internet has constantly been to "get information including news", followed by entertainment purposes. About one-third of Internet users surveyed carried out business-to-consumer electronic commerce in December 2000, a share that went up to 40\% in December 2004. In December 2004, almost 60\% of those engaged in e-commerce bought books and about one-third of the people bought computer appliances. The most important barrier to buying on line in December 2004 was doubts about the quality of the product people would like to buy. This barrier gained importance over the last few years, as security fears and inconvenient payment modes have become less important, although security fears have been rising again in importance since July 2002.

This study was done by a Japanese consultant for the OECD, as part of the outreach programme of the Economic Analysis and Statistics Division (EAS) of the Directorate for Science, Technology and Industry (DSTI) of the OECD. 
DSTI/DOC(2005)4

\title{
INDICATEURS OFFICIELS SUR LES TIC EN CHINE : TOUR D'HORIZON ET BILAN DE LA SITUATION
}

\author{
Masahiro Katsuno*
}

\section{Résumé}

Ce document examine la situation en matière de statistiques officielles des TIC en Chine et s'efforce d'évaluer le développement des TIC en Chine en se basant sur les informations existantes. Ce travail peut être considéré comme une première tentative de bilan. L'objectif serait d'accéder à une situation dans laquelle les données peuvent être collectées de manière plus systématique en Chine afin de pouvoir figurer dans des comparaisons internationales.

En Chine, les statistiques occupent une place particulière par rapport aux pays de l'OCDE : elles constituent un outil important pour démontrer les progrès accomplis au regard des objectifs quantitatifs fixés dans chaque plan quinquennal. Les données statistiques fournies par les différentes instances gouvernementales sont donc assez complètes, mais étant donné la finalité de ces statistiques, l'information n'est souvent pas comparable internationalement, ou elle ne l'est qu'en partie. La plupart des données des sources non officielles s'appuient sur les statistiques officielles. Le gouvernement chinois a récemment adopté une loi qui limite la collecte de données statistiques par des organismes étrangers, qu'ils soient privés ou gouvernementaux. Les informations statistiques d'origine autre que gouvernementale sont donc assez limitées. L'un des obstacles à la constitution par interclassement d'indicateurs cohérents à l'échelle du pays est la structure verticale des pouvoirs publics chinois, qui entrave la circulation de l'information entre ses différents ministères et avec les autres institutions qui sont chargées de la collecte de données. Pour ces raisons, il est difficile de compiler une série d'indicateurs pour comparer le développement en TIC de la Chine avec celui d'autres pays. Par exemple, ce document ne contient aucun indicateur concernant l'usage des TIC par les entreprises.

Cela étant, à partir des informations dont on dispose, on peut tirer provisoirement les conclusions qui suivent.

- La Chine développe rapidement sa production de différents types de produits de TIC. Les échanges de produits de TIC (importations comme exportations) sont passés d'à peine plus de $12 \%$ du total des échanges en 1996 à plus de $27 \%$ en 2003. La Chine devient rapidement l'un des grands pôles mondiaux de l'assemblage de produits de TIC. En 2003, plus de $60 \%$ des importations de produits de TIC correspondaient à des composants électroniques, alors que près des quatre cinquièmes des produits de TIC exportés étaient des équipements informatiques, de télécommunications, de son et de vidéo. Les salaires du secteur des services de TIC sont très élevés par rapport à ceux d'autres secteurs, et représentaient en 2002 plus de trois fois le salaire moyen national.

Directeur, Programme international, Institut de recherche en économie, commerce et industrie (RIETI), Tokyo ; e-mail : katsuno-masahiro@rieti.go.jp. Ce document a été rédigé lorsque l'auteur était consultant indépendant. Les opinions exprimées ici n'engagent que son auteur et ne reflètent pas nécessairement celles de l'OCDE ou de ses pays membres. 
- En matière de téléphonie, le nombre des abonnements progresse à un rythme soutenu, et en octobre 2003 le téléphone mobile a supplanté le fixe en termes d'abonnements. Les données sur la pénétration des principaux biens durables dans les ménages font apparaître un écart considérable entre les urbains et les ruraux. En termes de possession d'un PC, la fracture régionale se réduit: la région qui affichait le taux de pénétration le plus faible en 2002 se situait au niveau atteint par la quatrième province en 1998.

- La distribution géographique des noms de domaine chinois fait apparaître une plus forte concentration dans les municipalités de Beijing et Shanghai et dans la région du Guangdong sur la côte sud-est, qui ensemble totalisaient $60 \%$ des noms de domaine chinois jusqu'en 2002, puis moins de $50 \%$ en 2003. S'agissant du nombre d'internautes, la fracture numérique régionale tend à se résorber, puisque l'on observe une diminution de la part des municipalités de Beijing, de Shanghai et de la province de Guandgong au profit de la zone occidentale.

- La population des internautes comprend environ $40 \%$ de femmes et les moins de 35 ans en constituent plus de $80 \%$, contre près de $90 \%$ en décembre 1998. On assiste aussi à un rattrapage rapide de la proportion d'internautes au profil éducatif et au revenu modestes.

- Le premier objectif de base de l'utilisation de l'Internet demeure «l'accès à l'information, actualité comprise », suivi du loisir. En 2000, environ un tiers des internautes interrogés pratiquaient le commerce électronique B2C. En décembre 2004 ils étaient $40 \%$. En décembre 2004, près de $60 \%$ des internautes qui recouraient au commerce électronique achetaient des livres et environ un tiers des biens informatiques. Le principal obstacle à l'achat en ligne en 2004 était l'incertitude quant à la qualité des produits. Cet obstacle a pris plus d'importance depuis quelques années avec le recul des craintes à l'égard des moyens de paiement et l'amélioration de leur commodité - même si les préoccupations de sécurité ont de nouveau gagné en importance depuis juillet 2002.

Cette étude a été réalisée pour l'OCDE par un consultant japonais, dans le cadre du Programme d'activités en direction des non-membres de la Division des analyses économiques et des statistiques (AES) de la Direction de la science, de la technologie et de l'industrie (DSTI) de l'OCDE. 


\section{TABLE OF CONTENTS}

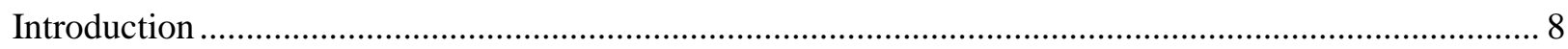

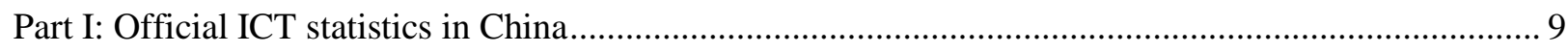

Role of relevant government agencies in the collection of statistics ................................................... 9

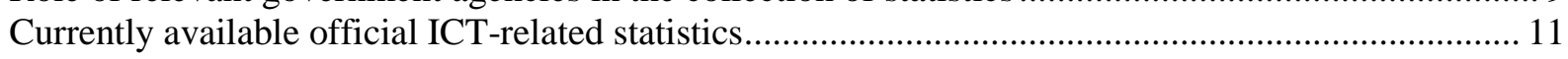

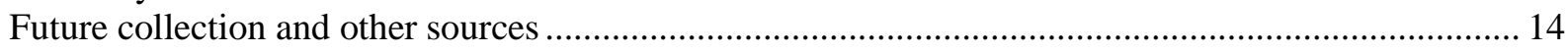

Part II: Analysis of available ICT statistics in China and current ICT development ............................... 15

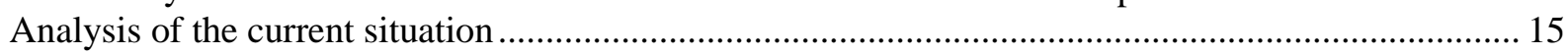

Historical background to the ICT sector development in China ....................................................... 16

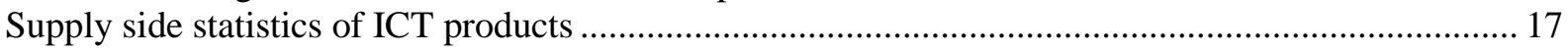

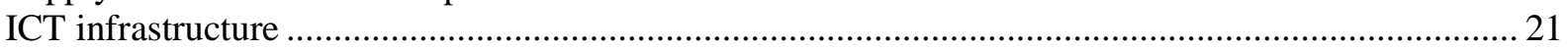

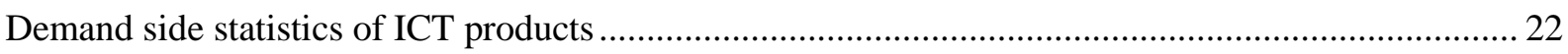

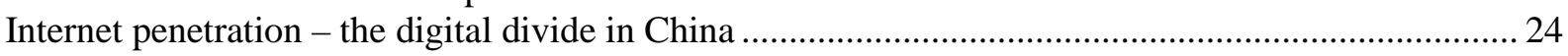

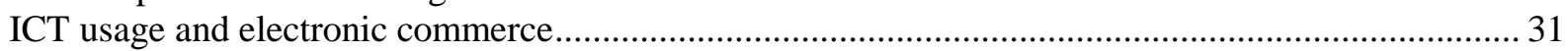

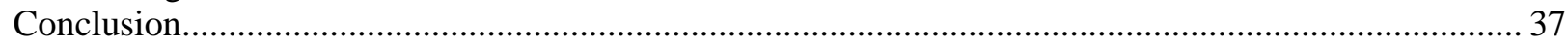

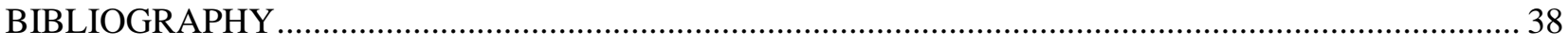

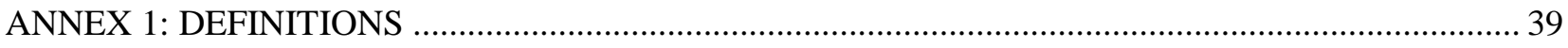

ANNEX 2: ICT PRODUCT CLASSIFICATION USED BY THE CHINESE MINISTRY OF

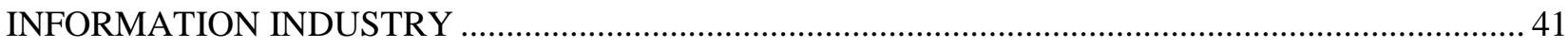




\section{Introduction}

This paper examines the state of official ICT statistics in China and tries to assess ICT development in China from the information currently available. The ultimate aim is to collect data from China more systematically, in order to compare these with data for OECD countries. Part I identifies the responsible ministries and their relevant departments and divisions. Part II provides an analysis of the available statistics to provide a general picture of the development of supply and use of ICT in China.

Statistics play a particularly unique role in China compared to other countries. While the ongoing economic reform is increasingly changing the planned economy aspect of China, quantitative goals, such as the volume of production of certain strategic goods, are specified for the country's economic development for each Five-Year Plan, and the progress is scrutinised during the National People's Congress. The provision of statistical data by various government bodies is therefore quite comprehensive. One of the important purposes of these statistics is to quantitatively show the progress made in each sector, and to confirm the good work of the responsible governmental bodies and party members supervising their work. Another important role of statistics in China is to project an image of a country that is developing fast, liberalising its economy and therefore a good place to invest. These factors need to be kept in mind when examining official statistics in China and interpreting the data.

The availability of other (non-official) statistical information is quite limited. Most "third-party" data are based on official statistics. The Chinese government recently passed legislation which restricts the collection of statistical data by foreign bodies, be they private or governmental (including international organisations). The regulation stipulates that foreign bodies conducting statistical collection need to work with a State-approved entity, which will conduct the actual statistical collection. This implies that, in theory, any recent statistical data are "official statistics" by definition.

A comprehensive range of official ICT statistics is available in China. Furthermore, because of the governmental control of each economic sector by the respective governmental ministries and bureaus, the relative power balance between the ministries and the business sector and the importance, albeit declining, of State Owned Enterprises (SOEs) within the Chinese economy, it seems relatively easy for the government bodies to collect statistics.

In addition to the above points that apply generally to official statistics in China, ICT statistics have a few specificities which need to be kept in mind:

- The ICT sector is a strategic sector, where China wants to attract foreign investment, developing its own technology base at the same time.

- The backbones of all Chinese Internet Service Providers (ISPs) go through a main backbone that is provided by the Chinese government. Because ISPs need to be approved by the government, it is very easy to carry out surveys related to the Internet.

- ICT statistics are a good source of income for the relevant ministries. There are a number of "private" statistical firms located in the IT centre of China (the Haidian District of Beijing and the Zhongguancun Area). However, those companies are mostly managed by ex-government officials (or sometimes even run by government officials). These firms have monopolistic access to official ICT statistics, which they sell at a high price to foreign firms. For this report, access to one such database was purchased from the Electronic Information Centre of the Ministry of Information Industry. 


\section{Part I: Official ICT statistics in China}

\section{Role of relevant government agencies in the collection of statistics}

By definition, government ministries are in charge of collecting statistics in the areas of the economic activity they supervise, from the enterprises that are under their jurisdiction. In the case of the ICT sector, as a rule the enterprises in this sector are under the supervision of the Ministry of Information Industry. ${ }^{1}$

There are three main sources of official ICT statistics in China:

- Ministry of Information Industry (and its subsidiary organisations) for network infrastructure statistics as well as ICT hardware statistics and Internet usage statistics.

- National Bureau of Statistics for general statistical figures, including ICT hardware production and employment statistics.

- Chinese Academy of Sciences for software sector statistics.

In addition to these government bodies, statistics provided by private companies that spun-off any of the above organisations can be considered official statistics, as the barrier between these private firms and the government organisations is not clear.

\section{Ministry of Information Industry (http://www.mii.gov.cn)}

The Ministry of Information Industry is responsible for the development of the growing information industry (not to be confused with the Ministry of Communication, which, in China, is responsible for transportation). It carries out its own statistical collection as well as delegating some to other entities, including the China Internet Network Information Centre (CNNIC).

The relevant departments are as follows:

- Department of International (External) Affairs. This department is responsible for organising the participation of the ICT industry in international organisations, co-ordination of intergovernmental agreements, processing intergovernmental communication, carrying out research pertaining to the ICT sector and foreign economic co-operation policy.

- Department of Economic Reform and Economic Management. This department's responsibilities include, among others, carrying out statistical monitoring and analysis related to the economic conditions of the ICT sector, making forecasts related to annual development targets in the ICT sector, ICT product market regulation and co-ordination of ICT product imports.

- Electronics Information Center (www.ceic.gov.cn). The Electronics Information Center falls directly under the supervision of the Ministry of Information Industry, and provides a platform of comprehensive information service on the information industry sector. Since its establishment in 1995, CEIC has been collaborating with government agencies, enterprises in the ICT sector and research organisations to provide timely and rich information on the information industry sector.

1. Other ministries also carry out business activities (such as Internet Service Provision) in the form of joint ventures. It is not clear if these activities are properly reflected in the official national statistics, but for the sake of this report, it is assumed that the enterprises supervised by the Ministry of Information Industry are representative of the ICT sector as a whole. 
The Web site allows access to a vast array of supply-side statistics in the ICT sector which can be purchased as a six-month subscription or a full-year subscription.

- China Internet Network Information Center (www.cnnic.net.cn). The China Internet Network Information Center (CNNIC) was founded on the 3 June 1997 as a non-profit organisation with the responsibility of being the National Internet Network Information Center (NIC), which assigns Internet domain names. CNNIC falls under the jurisdiction of the Ministry of Information Industry, and is administered by the Computer Network Information Center of the Chinese Academy of Sciences (see below). The CNNIC Working Committee ${ }^{2}$ supervises and evaluates the establishment, running and administration of CNNIC. Its functions include collecting statistics related to the state of development of the Internet in China.

\section{National Bureau of Statistics (www.stats.gov.cn)}

The National Bureau of Statistics (NBS) falls directly under the State Council and is responsible for collecting statistical information for all sectors of the Chinese society and economy. It also draws up regulations and laws which mandate other central government entities as well as local governments to carry out statistical surveys, supervises their activities and establishes definitions and methodologies for statistical collection. The NBS publishes monthly economic and social statistics, as well as an annual statistical yearbook, published on the Internet in Chinese.

The relevant departments are as follows:

- International Co-operation Department (Main Office): carries out, among other tasks, cooperation activities at both bilateral and multilateral level.

- Department of Statistical Design and Management: examines the methodologies and definitions used by the departments that actually carry out the statistical surveys.

- Industry and Transportation Statistics Department: carries out statistical collections related to the industry and transportation sector, and supervises other government entities conducting statistical surveys in this area.

- Enterprise Investigation Unit: carries out statistical collection at the enterprise level.

- International Statistical Information Center: carries out co-operation and exchange activities at bilateral and multilateral levels as well, but also carries out comparability studies with foreign statistics.

\section{Chinese Academy of Sciences (http://www.cashq.ac.cn)}

The Chinese Academy of Sciences (CAS) was founded in Beijing on the 1 November 1949 out of the former Central Academy of Sciences and the Beijing Academy of Sciences. It is the country's highest academic institution and comprehensive research and development centre in natural sciences, technological sciences and high-tech innovation. ${ }^{3}$ While this institution's mandate does not include the collection of statistics, many of the major Chinese software companies have spun-off from this institution. These Chinese software companies, which can be characterised as venture firms, are actually managed by

2. The Working Committee is headed by members of the Chinese Academy of Science and the Ministry of Information Industry.

3. CAS Web site. 
researchers of the CAS. As such, the institution holds a quasi-monopoly on statistics related to the software sector, which the institution markets to the outside world (e.g. to foreign IT firms and research companies) via other venture firms (also run by ex- and present researchers of the Academy) that are specialised in ICT statistics.

Relevant departments within this institution are:

- Bureau of Comprehensive Planning: undertakes, inter alia, statistical collection and analysis related to the work of the CAS, as well as firms that span-off CAS. The General Statistics Division is of particular relevance.

- Bureau of International Co-operation: carries out co-operation activities at bilateral and multilateral levels. The International Organisations Division which carries out co-operation with multilateral agencies is of particular relevance. ${ }^{4}$

\section{Currently available official ICT-related statistics}

General economic statistics including the ICT sector

National Bureau of Statistics

\begin{tabular}{|l|l|}
\hline Title & Variables \\
\hline $\begin{array}{l}\text { Monthly/Quarterly Statistics on } \\
\text { Economic and Social } \\
\text { Indicators }\end{array}$ & $\begin{array}{l}\text { Production volume and value added of industrial output by product (for the ICT } \\
\text { sector, this includes data for optical communication equipment, mobile } \\
\text { telecommunication equipment, mainframe computers, personal computers and } \\
\text { integrated circuits). }\end{array}$ \\
\hline Statistical Yearbook & $\begin{array}{l}\text { Annual production volume by product (see above for products in the ICT sector). } \\
\text { Employment and wages in the ICT sector. } \\
\text { Penetration ratios of consumer goods. } \\
\text { Telephone (mobile and fixed) penetration, length of various telecommunication lines, } \\
\text { number of telephone calls made and subscription to various telecom services. }\end{array}$ \\
\hline
\end{tabular}

\section{ICT hardware and software statistics}

Ministry of Information Industry

Detailed data on the ICT sector are collected by the Ministry of Information Industry. Some of the data are included in the annual statistical survey published by the National Bureau of Statistics, but much of the detailed information is being gathered at the Electronic Information Center, a subsidiary organisation of the MII. The Electronic Information Center is teaming up with a private firm, the China Center of Information Industry Development (a spin-off from the Ministry of Information Industry), to provide an ICT statistics database for CNY 6000 a year (roughly USD 730).

4. Intergovernmental organisations with which the CAS currently has international co-operation agreements include: UN-ESCAP, UNESCO, UNEP, UNDP and FAO. 


\begin{tabular}{|c|c|c|}
\hline Title and responsible body & Variables & $\begin{array}{l}\text { Method of statistical } \\
\text { collection }\end{array}$ \\
\hline $\begin{array}{l}\text { Electronics Industry Top } 100 \text { Firms } \\
\text { Major Product Production and Sales } \\
\text { Monthly Statistics; Ministry of } \\
\text { Information Industry, Department of } \\
\text { Economic Management. }\end{array}$ & $\begin{array}{l}\text { Annual production to date, total sales, total inventory, total } \\
\text { export (all in volume). } \\
\text { Products covered include: colour TVs, colour cathode ray } \\
\text { tubes, fixed telephones, personal computers, video recorders, } \\
\text { mobile telephones and computer screens. } \\
\text { A semi-annual summary is also published. }\end{array}$ & $\begin{array}{l}\text { These } 100 \text { firms are } \\
\text { under the jurisdiction of } \\
\text { the Ministry of } \\
\text { Information Industry, } \\
\text { and have the obligation } \\
\text { to report to the Ministry. }\end{array}$ \\
\hline $\begin{array}{l}\text { Electronics Industry Top } 100 \text { Firms } \\
\text { Monthly Production and Sales Indices; } \\
\text { Ministry of Information Industry, } \\
\text { Department of Economic Management. }\end{array}$ & $\begin{array}{l}\text { Production to date, sales to date and profit to date by the top } \\
100 \text { firms. }\end{array}$ & $\begin{array}{l}\text { These } 100 \text { firms are } \\
\text { under the jurisdiction of } \\
\text { the Ministry of } \\
\text { Information Industry, } \\
\text { and have the obligation } \\
\text { to report to the Ministry. }\end{array}$ \\
\hline $\begin{array}{l}\text { Information Industry Annual Report; } \\
\text { Ministry of Information Industry. }\end{array}$ & $\begin{array}{l}\text { Product-level data of ICT and other electronics products } \\
\text { including PCs (broken down to desktop, laptop, PDA), software } \\
\text { (broken down to OS-level, intermediary and application } \\
\text { software, which is further broken down), PC peripherals (floppy } \\
\text { disks, hard disks, optical disks, monitors and printers, which are } \\
\text { further broken down). } \\
\text { The data are further classified by location and form of the } \\
\text { enterprise. }\end{array}$ & $\begin{array}{l}\text { Firms contained in these } \\
\text { statistics have an } \\
\text { obligation to report to } \\
\text { the Ministry of } \\
\text { Information Industry. }\end{array}$ \\
\hline $\begin{array}{l}\text { Customs Import and Export Statistics } \\
\text { by Product Category; Ministry of } \\
\text { Information Industry and Customs } \\
\text { Office. }\end{array}$ & $\begin{array}{l}\text { Custom's data on product categories (telecommunications } \\
\text { equipment; broadcasting equipment; computers; household } \\
\text { electronics; electronic instruments; electronic parts; electronic } \\
\text { devices; electronic materials), measured in US dollars. } \\
\text { These data are categorised by form of enterprise; } \\
\text { importing/exporting region of the firm's location; and trading } \\
\text { partner (country). } \\
\text { The data are further disaggregated by product (see Annex } 2 \text { for } \\
\text { detailed classification used) and actual trade operation } \\
\text { recorded at customs. }\end{array}$ & $\begin{array}{l}\text { Statistics collected at the } \\
\text { customs level. }\end{array}$ \\
\hline $\begin{array}{l}\text { Monthly Statistics on Electronics } \\
\text { Industry Production; Chinese Center of } \\
\text { Information Industry Development; } \\
\text { CCIID Datasource. }\end{array}$ & $\begin{array}{l}\text { Production value, Sales of the sector according to } \\
\text { region/provinces, major cities and major enterprise groups. }\end{array}$ & $\begin{array}{l}\text { See Annex } 2 \text { for the } \\
\text { definition of electronics } \\
\text { industry. }\end{array}$ \\
\hline $\begin{array}{l}\text { Monthly (semi-annually for 1996-1998) } \\
\text { Statistics on the Status of Completed } \\
\text { Production in the Electronics Industry; } \\
\text { Chinese Center of Information Industry } \\
\text { Development, CCIID Datasource. }\end{array}$ & $\begin{array}{l}\text { Production value, sales and export in Yuan (CNY, in current } \\
\text { value and } 1990 \text { value) of the sector disaggregated into } \\
\text { investment goods, consumer goods, equipment goods, as well } \\
\text { as according to type of enterprise. }\end{array}$ & \\
\hline $\begin{array}{l}\text { Monthly Production and Sales } \\
\text { Statistics of Major Products of the } \\
\text { Electronics Industry; Chinese Center of } \\
\text { Information Industry Development, } \\
\text { CCIID Datasource. }\end{array}$ & $\begin{array}{l}\text { Production and sales volume of major products (mobile } \\
\text { telephones, telephone exchangers, fixed telephone units, fax } \\
\text { machines, televisions, tape recorders, stereos, DVD and VCD } \\
\text { players, video recorders, desktop and laptop PCs, servers, } \\
\text { computer displays, printers, electronic parts, cathode-ray tubes } \\
\text { (CRT), semiconductor separators, integrated circuits and CRT } \\
\text { glass tubes. }\end{array}$ & $\begin{array}{l}\text { Aggregated from firm- } \\
\text { level data collected by } \\
\text { the Ministry of } \\
\text { Information Industry. }\end{array}$ \\
\hline $\begin{array}{l}\text { Monthly Major Economic Indices of the } \\
\text { Electronics Industry (according to } \\
\text { province/region/cities); Chinese Center } \\
\text { of Information Industry Development, } \\
\text { CCIID Datasource. }\end{array}$ & $\begin{array}{l}\text { Number of firms, number of loss-making firms and sales value } \\
\text { of electronics industry (see Annex } 2 \text { for definition) according to } \\
\text { provinces/regions/cities and major enterprise groups. }\end{array}$ & $\begin{array}{l}\text { Aggregated from firm- } \\
\text { level data collected by } \\
\text { the Ministry of } \\
\text { Information Industry. }\end{array}$ \\
\hline $\begin{array}{l}\text { Detailed Monthly Major Economic } \\
\text { Indices of the Electronics Industry; } \\
\text { Chinese Center of Information Industry } \\
\text { Development, CCIID Datasource. }\end{array}$ & $\begin{array}{l}\text { Number of firms; sales income; sales cost, administrative cost, } \\
\text { financial cost including loan interest, profits; total value of } \\
\text { losses, corporate tax; total assets, total liabilities, average fluid } \\
\text { assets, industrial value added; number of employees (of which } \\
\text { laid-off workers } 5 \text { ); inventory; etc. }\end{array}$ & $\begin{array}{l}\text { Aggregated from firm- } \\
\text { level data collected by } \\
\text { the Ministry of } \\
\text { Information Industry. }\end{array}$ \\
\hline
\end{tabular}

5. This concerns the laid-off workforce included in the companies payrolls. 
There are also various monthly reports that are issued by the Ministry of Information Industry, which contain statistical data including, but not limited to the statistical data already listed above.

\begin{tabular}{|l|l|}
\hline Title and responsible body & Variables \\
\hline $\begin{array}{l}\text { Monthly (initially quarterly) } \\
\text { economic movement report of } \\
\text { the information industry; Ministry } \\
\text { of Information Industry. }\end{array}$ & $\begin{array}{l}\text { This report is primarily intended for the government to monitor the fulfilment of } \\
\text { planned targets, and hence analyses the data incorporated in the statistical tables } \\
\text { published by the Ministry of Information Industry, by providing comparisons over } \\
\text { time as well as comparisons with the planned quantity of production, which is } \\
\text { based on the production capacity of firms. }\end{array}$ \\
\hline $\begin{array}{l}\text { Monthly Digest Analysis of the } \\
\text { economic movement of the Top } \\
100 \text { Electronics and Information } \\
\text { enterprises; Ministry of } \\
\text { Information Industry. }\end{array}$ & $\begin{array}{l}\text { Summarises the main indicators covered in the statistical tables above according to } \\
\text { the main firms in the Top 100. }\end{array}$ \\
\hline
\end{tabular}

\section{ICT infrastructure statistics}

Ministry of Information Industry

The following statistics are available in Chinese:

\begin{tabular}{|l|l|l|}
\hline Title & Variables collected & Method of collection \\
\hline $\begin{array}{l}\text { Monthly report on major } \\
\text { telecommunication indices. }\end{array}$ & $\begin{array}{l}\text { Indices include the total sales of telecommunication } \\
\text { services; telecommunication investment stock; length } \\
\text { of optical network and digital microwave network; } \\
\text { number of fixed telephones and penetration, number } \\
\text { of mobile telephones and penetration; number of } \\
\text { Internet users. }\end{array}$ & $\begin{array}{l}\text { Reporting from } \\
\text { infrastructure } \\
\text { development projects. }\end{array}$ \\
\hline $\begin{array}{l}\text { Monthly report on post and } \\
\text { telecommunication development } \\
\text { and capacity development. }\end{array}$ & Approximately the same indices as above. & $\begin{array}{l}\text { Reporting from } \\
\text { infrastructure } \\
\text { development projects. }\end{array}$ \\
\hline $\begin{array}{l}\text { Monthly report on post and } \\
\text { telecommunication development } \\
\text { and capacity development; 1997 } \\
\begin{array}{l}\text { Post and Telecommunication } \\
\text { Annual Report (covering annual } \\
\text { data for 1993 to 1997). }\end{array}\end{array}$ & $\begin{array}{l}\text { Above indices plus labour productivity in the post and } \\
\text { telecommunication sector. }\end{array}$ & $\begin{array}{l}\text { Reporting from } \\
\text { infrastructure } \\
\text { development projects. }\end{array}$ \\
\hline
\end{tabular}

The National Academy of Sciences also produces computer-software related statistics, but the source of the raw data is the same as the statistics provided by the Ministry of Information Industry.

Statistics related to the Internet and its uses

Ministry of Information Industry - China Internet Network Information Center

The Ministry of Information Industry has officially delegated the CNNIC to carry out semi-annual survey on Internet usage since 1997. For the past few years, the data have come out in January and July for surveys ending in December and June respectively. 


\begin{tabular}{|c|c|c|}
\hline Title & Variables & Method of statistical collection \\
\hline $\begin{array}{l}\text { Monthly Statistics } \\
\text { on Domain Names } \\
\text { under CN. }\end{array}$ & $\begin{array}{l}\text { Number of domain names registered } \\
\text { under } \mathrm{CN},(\mathrm{AC}, \mathrm{COM}, \mathrm{EDU}, \mathrm{GOV}, \mathrm{NET} \text {, } \\
\text { ORG) as well as Administration Area } \\
\text { Domain Name (AADN). }\end{array}$ & $\begin{array}{l}\text { CNNIC is the organisation in charge of assigning } \\
\text { and registering domain names in China. }\end{array}$ \\
\hline $\begin{array}{l}\text { Semi-annual } \\
\text { Survey Report on } \\
\text { the Development of } \\
\text { China's Internet. }\end{array}$ & $\begin{array}{l}\text { Computer hosts in China, Internet users in } \\
\text { China, domain name statistics according } \\
\text { to suffix, region/province/city, total } \\
\text { bandwidth of backbone (leased } \\
\text { international connections) according to } \\
\text { type of backbone, profile of Internet users } \\
\text { (gender, age, civil status, geographical } \\
\text { distribution, education, profession, } \\
\text { income, location of access, access } \\
\text { expenditure, time spent on the Internet, } \\
\text { activities on the Internet, e-commerce } \\
\text { details, opinions on various "hot" issues). }\end{array}$ & $\begin{array}{l}\text { Domain name statistics are obtained through } \\
\text { CNNIC's main activity as China's NIC. } \\
\text { Bandwidth information is obtained from the Ministry } \\
\text { of Information Industry, the regulating government } \\
\text { body of the Internet. Statistics related to Internet } \\
\text { users are based on on-line and off-line surveys } \\
\text { carried out with the collaboration of Internet } \\
\text { Service Providers (ISPs) which are under the } \\
\text { jurisdiction of the Ministry of Information Industry, } \\
\text { and hence have the obligation to provide statistical } \\
\text { data. The on-line surveys have approximately } \\
20000 \text { to } 60000 \text { valid responses and } \\
\text { approximately } 4000-6000 \text { valid responses are } \\
\text { double-checked through off-line/telephone surveys. }\end{array}$ \\
\hline $\begin{array}{l}\text { Annual Survey } \\
\text { Report on the } \\
\text { Quantity of China's } \\
\text { Internet Information } \\
\text { Resources. }\end{array}$ & $\begin{array}{l}\text { Number of domain names; number of } \\
\text { Web sites; number of Web site pages; } \\
\text { number of on-line databases. }\end{array}$ & \\
\hline
\end{tabular}

\section{Future collection and other sources}

\section{Chinese domestic entities}

There are various quasi-governmental institutions (central as well as local government) and business/industry organisations that collect statistics. Often, the board of governors (sometimes the chairman) includes officials of the Ministry of Information Industry. It is hence likely that statistical figures coming from these entities are official statistics originating from the Ministry of Information Industry, which they process for their own needs.

A list of these institutions includes:

- Academy of Sciences, MOFTEC.

- Beijing International Trade Research Institute (mysc@tpbj.go.cn).

- Beijing Research Centre for Development of Electronic Industry.

- China Sciences and Technical Information Institute.

- Research Institute of Commerce and Economics.

- $\quad$ State Bureau of Internal Trade.

- China Information Industry Association.

- China Mobile Communications Association (www.cca.org.cn). 
- China Semiconductor Industry Association.

- China Software Industry Association (www.csia.org.cn).

- China Computer Federation (www.ccf.org.cn).

- China Institute of Communications (www.china-cic.org.cn).

- China Chamber of Commerce for Information Industry.

- China Computer Industry Association (www.chinaccia.org.cn).

- Internet Society of China (www.isc.org.cn).

- China Association of Communication Enterprises (www.cace.org.cn).

- China Communication Industry Association (www.ccia.org.cn).

- China Electronic Commerce Association (www.ceca.net.cn).

- China Electronics Chamber of Commerce (www.cecc.org.cn).

\section{Part II: Analysis of available ICT statistics in China and current ICT development}

\section{Analysis of the current situation}

Current official ICT statistics in China are concentrated mainly on the supply side, except for statistics collected by the National Bureau of Statistics. However, statistics published by the NBS are not very detailed as far as the ICT sector is concerned. ${ }^{6}$

Detailed ICT supply-side statistics can be obtained from the Ministry of Information Industry. As far as ICT statistics go, government-related institutions are taking the place of private consulting firms and think-tanks (such as IDC, Forrester, McKinsey, Boston Consulting) in raising revenues from the sales of these statistics. Because government agencies have the monopoly on official ICT statistics, this situation could be disadvantageous to the further development of official ICT statistics, because this means that there is no competition in providing currently unavailable statistics, such as demand-side statistics, especially with regard to ICT penetration in firms, government and education.

The barriers between government agencies, each of which is responsible for certain sectors of the economy, might be a reason for making demand-side statistical collection difficult, such as ICT penetration in firms, because of the very close relationship between the ministries and the firms that are under their administrative supervision.

Definitions of statistical data seem to be most comprehensive and transparent for those collected by the National Bureau of Statistics. Statistics collected by the Ministry of Information Industry use a product categorisation that best matches its reporting responsibilities, but which may not fit international standards. The definitions are not as clear as those of the National Bureau of Statistics. When it comes to statistics by

6. It is conceivable that the underlying data behind the demand-side statistics provided by NBS are available either at NBS or with the Ministry of Information Industry, but these data were not identified by the author in either of these organisations. 
the China Network Information Center (CNNIC), the survey method used varies considerably from survey to survey in terms of the number of people surveyed. Judging from the results, the surveys themselves seem to be using different criteria (such as age cut-off, profession) making it difficult to analyse the trends.

\section{Historical background to the ICT sector development in China ${ }^{7}$}

\section{Semiconductor industry}

China's semiconductor industry started in the early 1950s. Transistor technology was transferred to China from the Soviet Union in 1953, and an entirely locally-manufactured transistor was produced in 1958. During the Second Five-Year Plan, starting in 1958, the electronics industry (including the semiconductor industry) was treated as a strategic sector, although until 1969 practically all of the production went into military usage. Integrated circuits (IC) technology was brought into China in the 1960s, but its production was kept at a small scale (4.2 million units in 1970). Moreover, in 1972, in the middle of the Cultural Revolution, a political debate took place whether to prioritise steel production or electronics production. Steel production was given priority, leading to a decline in electronics production. In 1978, the economic reform policies brought civilian IC production technologies from abroad and the semiconductor industry attracted attention as a result. In 1988, IC production reached 100 million units, staying roughly at the same level for the next six years. Production started to increase with a rush in foreign investment in this sector, which started in 1992, bringing the production to 245 million units in 1994, 515 million units in 1995, 790 million units in 1996 and 2.1 billion units in 1997. However, the production level is still not adequate to meet domestic demand. IC production technology is also two to three generations behind leading edge technology. In 1997, there were 34 firms in China's semiconductor industry, almost half of them foreign-affiliated.

\section{Electronics industry (communication hardware and computers)}

The electronics industry in China also developed through China's involvement in the Korean War, during which short-wave radios and military telephones were produced. During the First Five-Year Plan (from 1953), the electronics industry was placed under the jurisdiction of the Ministry of the Second Machinery Industry (Ministry of Defence Industry). In 1958, the first Chinese vacuum tube computer was produced, based on a Soviet model. The first transistor computer was produced in 1965 (a total of 256 units were produced) mainly for military purposes, while IC-based computers started to be produced in the 1970s (1672 units produced by 1978), which were used for civilian purposes as well. In the 1980s, personal computers from manufacturers such as IBM and Apple started to penetrate the Chinese market, and local manufacturers such as Great Wall (Chang Cheng - a State-Owned Enterprise) started to make clones of these machines. However, the share of local computers remained low (within enterprises, the share of locally-manufactured computers was $31.5 \%$ in 1985 , while it was $31.1 \%$ for personal computers). This situation of rivalry between State-Owned Enterprises and foreign-affiliated enterprises, which existed in the telephone exchange market as well, changed in the second half of the 1990s with the rise of various venture firms such as Legend and Founder in the PC market.

\section{Telecommunications}

The communication sector has been considered by the Chinese government as a strategic sector together with railways and electricity production. However, telephone penetration remained quite low (at around $0.4 \%$ in 1980 just after the reform process started). Telecommunication infrastructure development was given priority and as a result telephone penetration (measured here as telephone subscribers per 100 inhabitants) went up to $1.1 \%$ in 1990 and $12 \%$ in 1999 (28.4\% in urban areas), after which it rapidly

7. Compiled from Maruyama (2000). 
increased. In July 2004, penetration of fixed phones was $22.9 \%$, while mobile penetration reached $23.7 \%$. Improvement in the basic telecommunication infrastructure led to the development of value-added services such as mobile telephony, data-communication, paging services and electronic mail, which were gradually deregulated and opened to domestic competitors of the state monopoly, the Ministry of Post and Telecommunication. Regulatory reform took place in the basic telecommunication sector as well, as in 1994 China Unicom (a venture between the former Ministry of Electronic Industry and the electricity and the railway sector) was allowed to enter this market. At the time of deregulation, China Telecom was separated from the government agency it was controlling, and currently China Unicom has gradually increased its share in the face of China Telecom's quasi monopoly, along with China Mobile as a new competitor. In 1998, further reform hit the telecommunication sector, as the Ministry of Post and Telecommunication, the Ministry of Electronic Industry and the Ministry of Radio and Television were merged to become the Ministry of Information Industry.

Currently, China is targeting the ICT sector as a strategic sector, which will help China leapfrog in its modernisation process. Already, the value of production of PC-related goods in China in 2000 was USD 25.5 billion, closely following the United States (at USD 103.4 billion) and Japan (USD 45.4 billion). ${ }^{8}$ But China is not only developing as an ICT hardware production centre. While the Southern Coastal region of China is developing as an ICT hardware production centre, the Zhongguancun area in the outskirts of Beijing is quickly becoming a software development centre. Unlike India, which is specialising in software development alone, China's development in the ICT sector can be characterised as a balanced development of both the hardware and software sectors.

\section{Supply side statistics of ICT products}

Supply side statistics of ICT-related products are available in aggregated form from the National Bureau of Statistics. Disaggregated data, which are said to be the basis on which the aggregated statistics are obtained, are available in very detailed form from the Ministry of Information Industry. ${ }^{9}$

A characteristic of Chinese statistics is that supply statistics are available in terms of the amount of goods produced, and monetary values are not associated with them except for custom statistics. Probable causes include regional price discrepancies, leading to difficulties in measurement, and the emphasis placed on amounts produced as opposed to the value (a remnant of the planned economy).

There are some coherency problems between the disaggregated data of the Ministry of Information Industry and those supplied by the National Bureau of Statistics. Similar problems exist within the various statistics reported by the Ministry of Information Industry itself. ${ }^{10}$ After talking to officials of international organisations and aid agencies in China that are involved in statistics, it seems likely that these discrepancies come from different kinds of statistical processing, which is common in China. Nevertheless, statistics from different official sources still give an indication of the existing situation.

The production of personal computers (including servers, desktop PCs and laptop PCs, but excluding mini/micro-computers and workstations) has been increasing dramatically since 1995 (see Table 1). This

8. Chinese Taipei Ministry of Economy.

9. Firm level data are collected annually from all "Electronics Industry" firms that are under the jurisdiction of (and hence have a reporting obligation to) the Ministry of Information Industry. Data is collected more frequently for the "Top 100" firms in the sector.

10. Queries were sent to both parties to resolve the discrepancy, but no reply was received. Observed problems include the annual sum of disaggregated data not matching the amount reported in the annual aggregated data, and the sum of product sub-categories not matching the amount reported for the sub-category total. 
production level exceeds production levels in many OECD countries. Japan, for example, produced 12 million units in 2000 .

Table 1. Growth in PC production (thousand units)

\begin{tabular}{|l|r|r|r|r|r|r|r|r|r|}
\hline & $\mathbf{1 9 9 5}$ & $\mathbf{1 9 9 6}$ & $\mathbf{1 9 9 7}$ & $\mathbf{1 9 9 8}$ & $\mathbf{1 9 9 9}$ & $\mathbf{2 0 0 0}$ & $\mathbf{2 0 0 1}$ & $\mathbf{2 0 0 2}$ & $\mathbf{2 0 0 3}$ \\
\hline Production & 836 & 1388 & 2066 & 2914 & 4050 & 6720 & 8777 & 14635 & 23167 \\
\hline
\end{tabular}

Source: National Bureau of Statistics, China Statistical Yearbook 1996-2004.

Mobile telephones are penetrating rapidly among Chinese consumers, while the production of mobile phones is increasing rapidly as well (see Table 2). However, about 50\% of the production is being exported.

Table 2. Production and sales volume of major ICT products (thousand units)

\begin{tabular}{|c|c|c|c|c|c|}
\hline & & 1998 & 1999 & 2000 & 2001 \\
\hline \multirow[t]{2}{*}{ Mobile phones } & Production & & 23000 & 83510 & 74950 \\
\hline & Sales & & 19200 & 79230 & 70640 \\
\hline \multirow[t]{2}{*}{ Desktop PC } & Production & 2880 & 3970 & 7580 & 6380 \\
\hline & Sales & 2620 & 3820 & 7510 & 6320 \\
\hline \multirow[t]{2}{*}{ Server } & Production & & & 100 & 90 \\
\hline & Sales & & & 100 & 90 \\
\hline \multirow[t]{2}{*}{ Laptop PC } & Production & & & 80 & 80 \\
\hline & Sales & & & 80 & 80 \\
\hline \multirow[t]{2}{*}{ PC Screens } & Production & 7190 & 17730 & 33560 & 30260 \\
\hline & Sales & 4970 & 17280 & 32030 & 29220 \\
\hline \multirow[t]{2}{*}{ PC Printer } & Production & & 700 & 6030 & 5080 \\
\hline & Sales & & 570 & 6010 & 4950 \\
\hline \multirow[t]{2}{*}{ IC / LSI } & Production & & 2289980 & 5482720 & 4740780 \\
\hline & Sales & & 2215220 & 5395870 & 4636580 \\
\hline
\end{tabular}

Notes: Data for 2001 are for January to November. Data are compiled from monthly statistics provided by the Ministry of Information Industry, but it should be noted that calculations within the monthly tables (including \% increase from the same period during the previous year) were sometimes not coherent.

Source: Ministry of Information Industry, Monthly statistics of major ICT products production and sales.

In 2003, the OECD member countries - through their Working Party on Indicators for the Information Society (WPIIS) - agreed on a product-based definition of ICT goods, based on the Harmonised System. ${ }^{11}$ The ICT goods definition consists of a list of six-digit HS categories, grouped into the following broad categories: telecommunications equipment, computer and related equipment, electronic components, audio and video equipment and other ICT goods.

11. OECD (2003). Note that this classification concerns goods only, a list of ICT services is still under discussion. 
Using the OECD ICT goods definition, Figure 1 shows that Chinese imports and exports of ICT goods have been increasing steadily since 1996, and that imports and exports are more or less in balance.

Figure 1. Chinese trade in ICT goods (millions of USD)

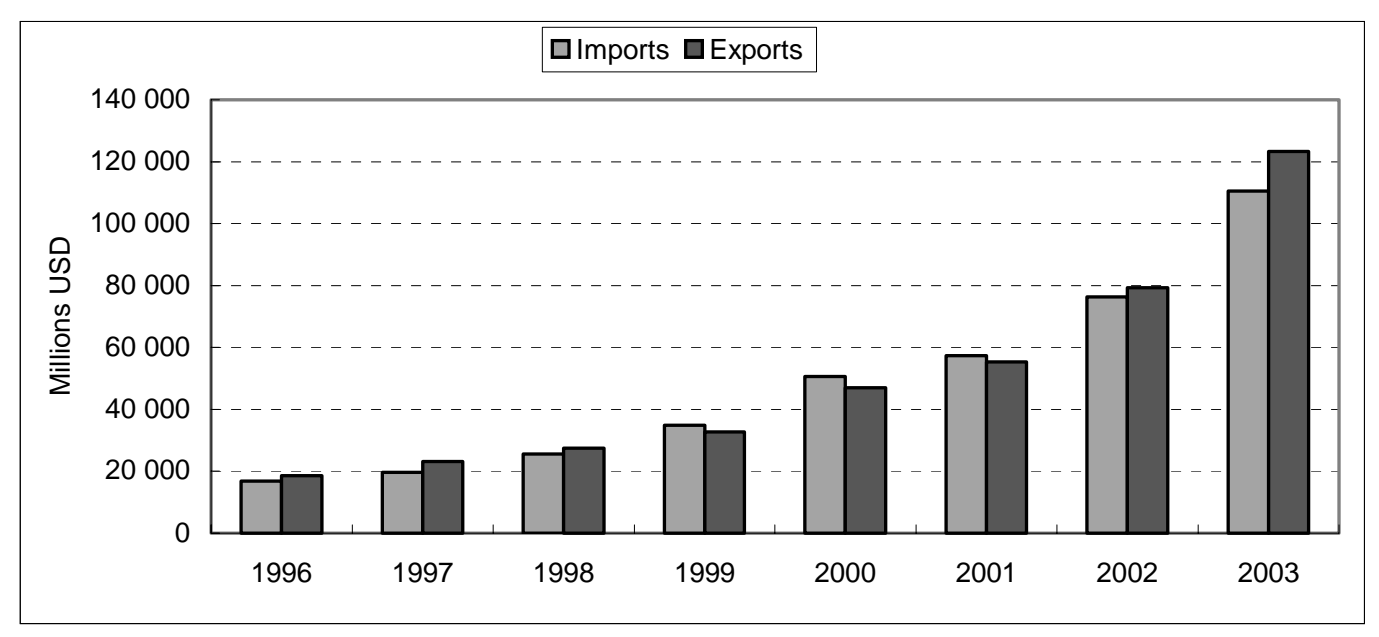

Source: OECD, ITCS database.

Table 3 further shows that ICT goods trade has assumed an ever-increasing share of total trade during the 1990s.

Table 3. Share of ICT goods in total trade in goods (\%)

\begin{tabular}{|l|c|c|c|c|c|c|c|c|}
\hline & $\mathbf{1 9 9 6}$ & $\mathbf{1 9 9 7}$ & $\mathbf{1 9 9 8}$ & $\mathbf{1 9 9 9}$ & $\mathbf{2 0 0 0}$ & $\mathbf{2 0 0 1}$ & $\mathbf{2 0 0 2}$ & $\mathbf{2 0 0 3}$ \\
\hline ICT imports as a \% of total imports & 12.1 & 13.8 & 18.2 & 21.0 & 22.5 & 23.5 & 25.9 & 26.8 \\
\hline ICT exports as a \% of total exports & 12.3 & 12.7 & 14.9 & 16.8 & 18.9 & 20.8 & 24.4 & 28.1 \\
\hline
\end{tabular}

Source: OECD, ITCS database.

According to data from the Ministry of Information Industry, in 2001, the only category of goods that China imported more than it exported (aside from the sub-category of dot-matrix printers) was in Integrated Circuits (IC/LSI), basic components of other ICT goods, which includes memory and controller chips including CPUs. China is still not self-sufficient in semiconductor production, both in terms of quantity as well as in terms of producing leading-edge products, hence its reliance on imports. China is quickly becoming a major assembly line for ICT goods production.

This finding is supported by data using the OECD definition of ICT goods. Figure 2 shows that $61 \%$ of Chinese imports of ICT goods in 2003 consisted of electronic components, while $79 \%$ of exports consisted of computer, telecommunications, audio and video equipment. 
Figure 2. Composition of Chinese trade in ICT goods, 2003

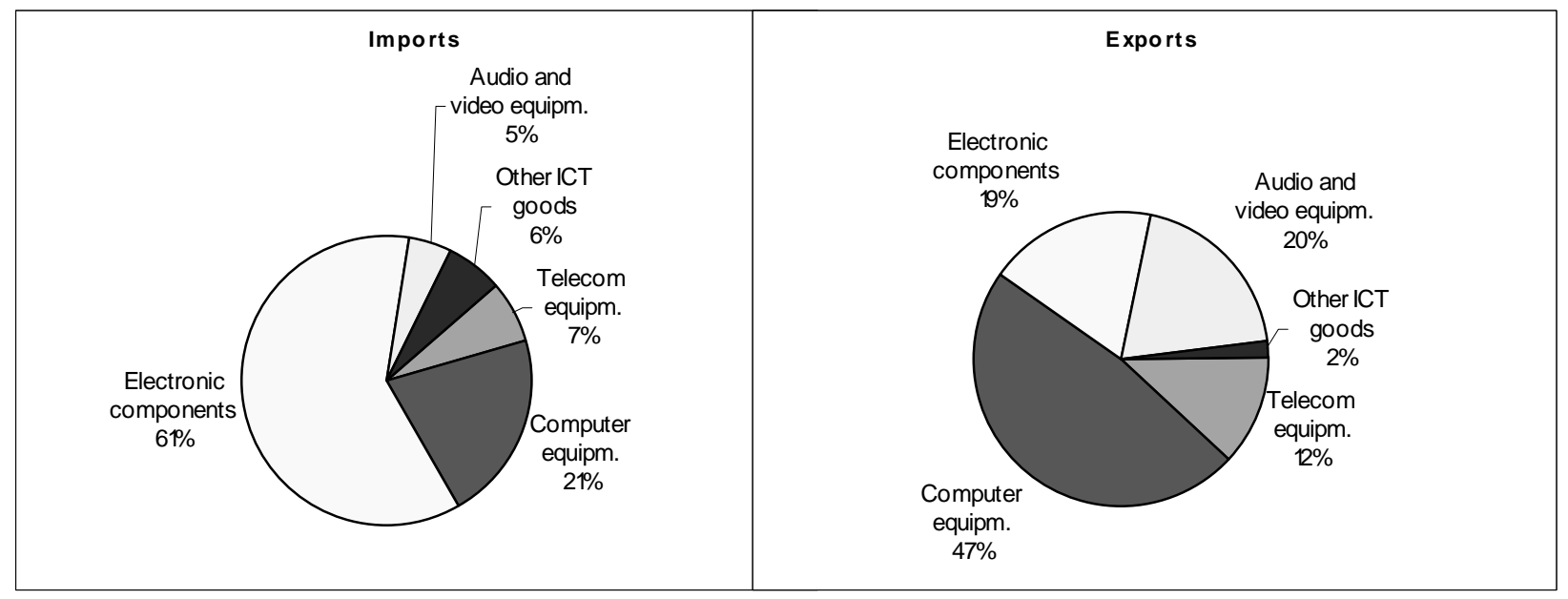

Source: OECD, ITCS database.

Employment statistics are a very sensitive issue in China, especially in view of the fact that the Chinese authorities want to portray a low unemployment rate. In spite of this, Table 4 shows that employment in the manufacturing sector is declining despite the increase in overall employment. An increase in productivity in this sector seems to be taking place.

Table 4. Number of persons employed and number of staff and workers in various sectors

\begin{tabular}{|l|r|r|r|r|r|r|r|r|}
\hline & $\mathbf{1 9 9 5}$ & $\mathbf{1 9 9 6}$ & $\mathbf{1 9 9 7}$ & $\mathbf{1 9 9 8}$ & $\mathbf{1 9 9 9}$ & $\mathbf{2 0 0 0}$ & $\mathbf{2 0 0 1}$ & $\mathbf{2 0 0 2}$ \\
\hline Economically active population (millions) & 688 & 698 & $\mathbf{7 0 8}$ & $\mathbf{7 2 1}$ & $\mathbf{7 2 8}$ & 740 & 744 & 754 \\
\hline Number of employed persons (millions) & 681 & 690 & 698 & 706 & 714 & 721 & 730 & 737 \\
\hline Number of staff and workers (millions) & 149 & 149 & 147 & 123 & 118 & 113 & 108 & 106 \\
\hline Staff and workers in the manufacturing sector (millions) & 54 & 53 & 51 & 38 & 35 & 32 & 30 & 29 \\
\hline Staff and workers in ICT services (thousands) & 55 & 52 & 61 & 56 & 69 & 93 & 124 & 179 \\
\hline
\end{tabular}

Note: For the difference between employed persons and staff and workers, see Annex 1. ICT Services Sector is denoted as Computer Application Services and is included in Social Services.

Source: China Statistical Yearbook 1996-2003.

In Table 5 it can be seen that wages in the ICT services sector (denoted as Computer Application Services) are very high compared to that of other sectors, more than three times the national average in 2002 , and double that in the financial and insurance sector.

Table 5. Annual average wage of staff and workers in various sectors (CNY)

\begin{tabular}{|l|r|r|r|r|r|r|r|r|}
\hline & $\mathbf{1 9 9 5}$ & $\mathbf{1 9 9 6}$ & $\mathbf{1 9 9 7}$ & $\mathbf{1 9 9 8}$ & $\mathbf{1 9 9 9}$ & $\mathbf{2 0 0 0}$ & $\mathbf{2 0 0 1}$ & $\mathbf{2 0 0 2}$ \\
\hline ICT services & $\mathbf{8 6 8 9}$ & 13930 & 17416 & 15385 & 19150 & 28333 & 30146 & 38810 \\
\hline Manufacturing & 5169 & 5642 & 5933 & 7064 & 7794 & 8750 & 9774 & 11001 \\
\hline Transport, post and telecom & 6948 & 7870 & 8600 & 9808 & 10991 & 12319 & 14167 & 16044 \\
\hline Financial and insurance & 7376 & 8406 & 9734 & 10633 & 12046 & 13478 & 16277 & 19135 \\
\hline Health and social welfare & 5860 & 6790 & 7599 & 8493 & 9664 & 10930 & 12933 & 14795 \\
\hline Education and culture & 5435 & 6144 & 6759 & 7474 & 8510 & 9482 & 11452 & 13290 \\
\hline Government & 5526 & 6340 & 6981 & 7773 & 8978 & 10043 & 12142 & 13975 \\
\hline National average & 5500 & 6210 & 6470 & 7479 & 8346 & 9371 & 10870 & 12422 \\
\hline
\end{tabular}

Note: ICT Services Sector is denoted as Computer Application Services and is included in Social Services.

Source: China Statistical Yearbook 1996-2003. 


\section{ICT infrastructure}

The ICT infrastructure is growing rapidly in China (see Table 6). Emphasis has been placed on digital infrastructure, including digital optical lines and copper lines.

Table 6. Development of telecommunications facilities

\begin{tabular}{|l|c|c|c|}
\hline & $\begin{array}{c}\text { Number of long distance } \\
\text { telephone lines }\end{array}$ & $\begin{array}{c}\text { Length of long distance } \\
\text { optical cable lines } \mathbf{( k m})\end{array}$ & $\begin{array}{c}\text { Length of long distance } \\
\text { microwave lines } \mathbf{( k m})\end{array}$ \\
\hline 1990 & 112437 & 3334 & 33626 \\
\hline 1991 & 151779 & 6490 & 39282 \\
\hline 1992 & 234276 & 14388 & 54418 \\
\hline 1993 & 420323 & 38666 & 64368 \\
\hline 1994 & 615809 & 73290 &.. \\
\hline 1995 & 735545 & 106882 & 79634 \\
\hline 1996 & 998287 & 130159 & 71503 \\
\hline 1997 & 1146121 & 150754 & 65013 \\
\hline 1998 & 1576483 & 194100 & 66518 \\
\hline 1999 & 1869671 & 239735 & 65228 \\
\hline 2000 & 2201746 & 286642 & 121947 \\
\hline 2001 & 3393300 & 399082 & 164052 \\
\hline 2002 & $\ldots$ & 487684 & 193636 \\
\hline 2003 & $\ldots$ & 594303 & 119886 \\
\hline
\end{tabular}

Source: China Statistical Yearbook 1996-2004.

China is still at a stage where telephone subscription is increasing at a fast rate (see Figure 3). Considering the low penetration rate of telephony, especially in rural areas, the trend is likely to continue. The number of Internet subscribers has been growing rapidly as well.

Figure 3. Usage of communication facilities (millions)

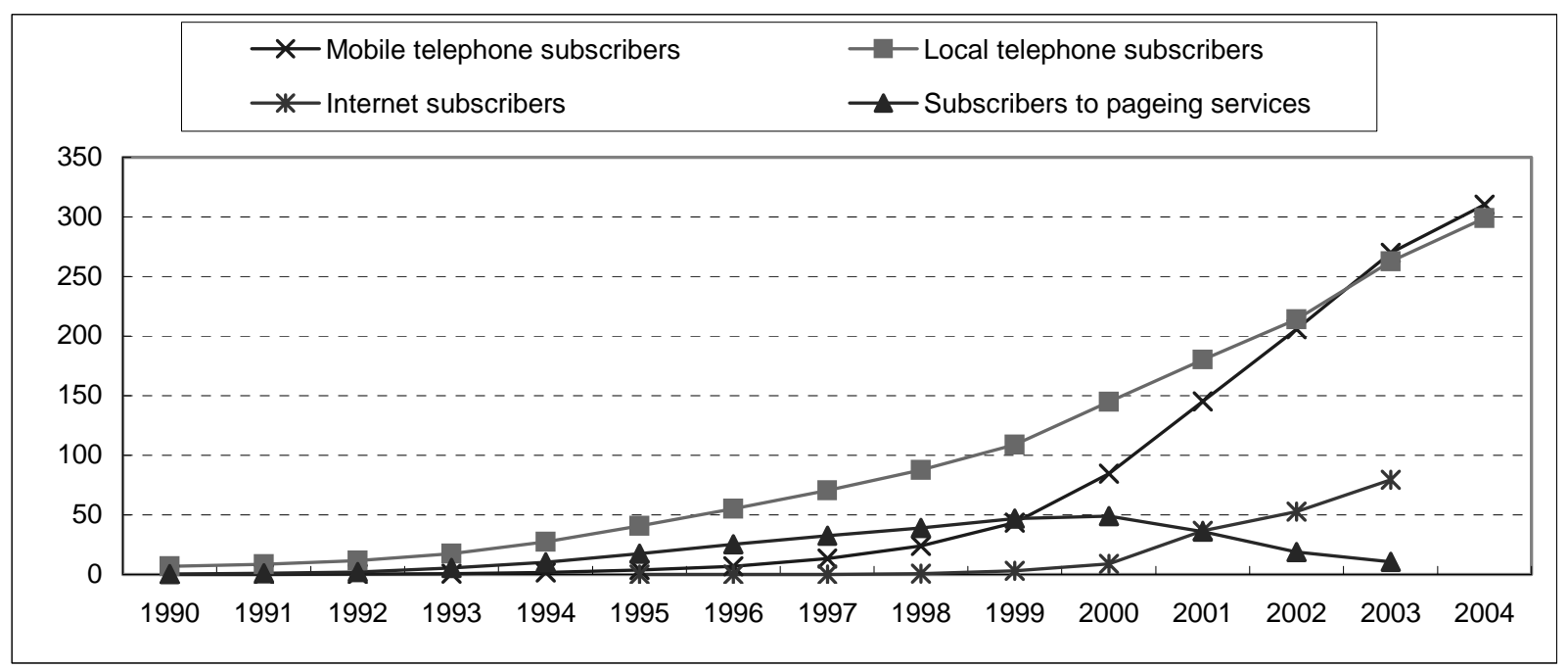

Source: China Statistical Yearbook 1996-2004. 
Together with the fast adoption of the Internet, China is quickly improving its backbone infrastructure (see Figure 3), with the national infrastructure, Chinanet, constantly holding more than half of the backbone.

Figure 4. Total bandwidth of the Internet backbone (Mbps)

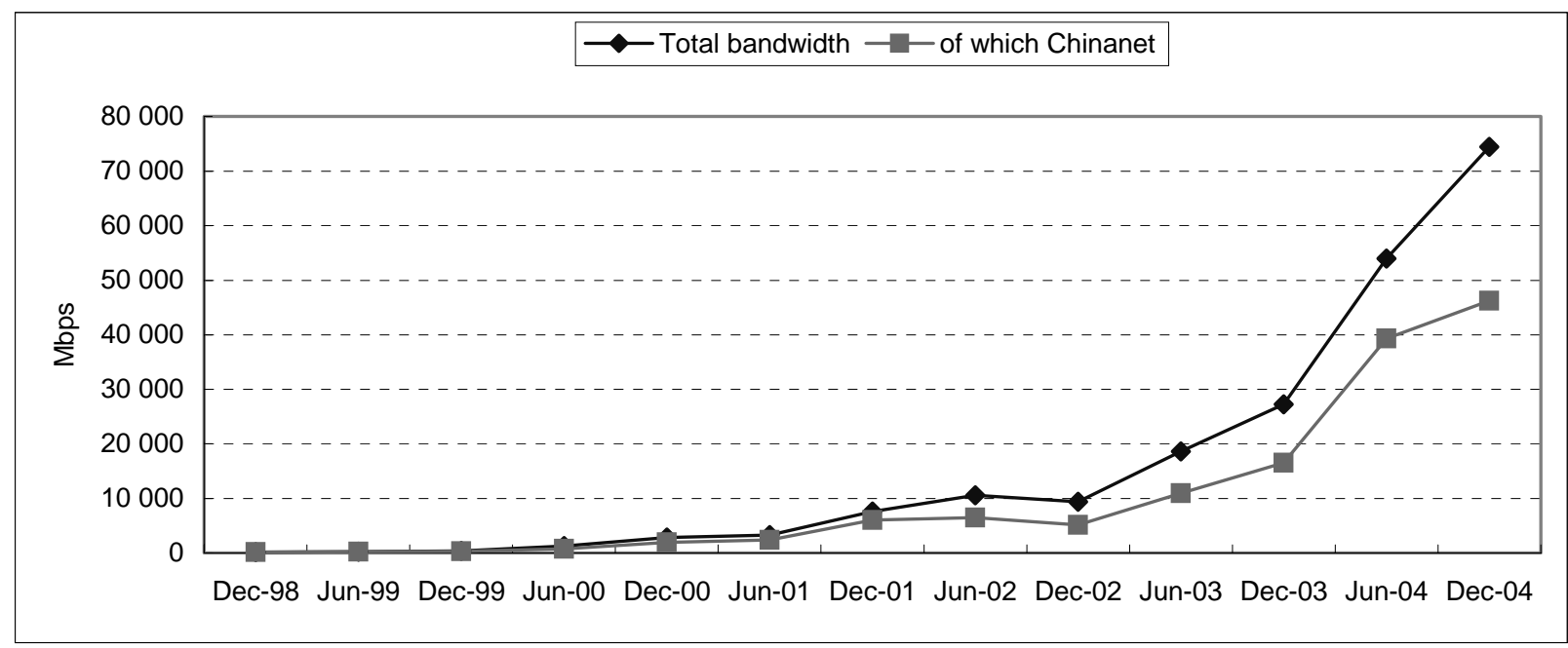

Note: Chinanet is the state-run backbone of Internet (under the jurisdiction of the Ministry of Information Industry). Source: Statistical Report of the Development of China Internet (January 1999 - January 2005).

\section{Demand side statistics of ICT products}

Demand side statistics of the ICT sector are even harder to grasp than the supply-side counterparts, partly because supply-side statistics are in essence an aggregate of firm-level data - which the firms are obligated to submit to the authorities to some extent - whereas demand-side statistics rely on census and predictions based on partial census data.

Table 7 shows that PC penetration in urban households is roughly doubling every two years since 1997. Although fast, it is not comparable to the penetration of mobile phones which was close to doubling every year until 2002. The urban/rural breakdowns for the years 2000 to 2003 show the huge digital divide within China.

Table 7. Penetration of durable consumer goods in urban and rural households at year end (units per 100 households)

\begin{tabular}{|l|r|r|r|r|r|r|r|r|r|r|r|}
\hline & $\mathbf{1 9 9 7}$ & $\mathbf{1 9 9 8}$ & $\mathbf{1 9 9 9}$ & \multicolumn{2}{|c|}{$\mathbf{2 0 0 0}$} & \multicolumn{2}{|c|}{$\mathbf{2 0 0 1}$} & \multicolumn{2}{|c|}{$\mathbf{2 0 0 2}$} & \multicolumn{2}{|c|}{$\mathbf{2 0 0 3}$} \\
\hline & urban & urban & urban & urban & rural & urban & rural & urban & rural & urban & rural \\
\hline PC & 2.6 & 3.8 & 5.9 & 9.7 & & 13.3 & & 20.6 & 1.1 & 27.8 & \\
\hline Mobile phone & 1.7 & 3.3 & 7.1 & 19.5 & 4.3 & 34.0 & 8.1 & 62.9 & 13.7 & 90.1 & 23.7 \\
\hline Colour TV & 100.5 & 105.4 & 111.6 & 116.6 & 48.7 & 120.5 & 54.4 & 126.4 & 60.5 & 130.5 & 67.8 \\
\hline Video disc player & 7.9 & 16.0 & 24.7 & 37.5 & & 42.6 & & 52.6 & & 58.7 & \\
\hline Video recorder & 21.3 & 21.7 & 21.7 & 20.1 & 3.3 & 19.9 & 3.3 & 18.4 & 3.3 & 17.9 & 3.5 \\
\hline HiFi system & 15.3 & 17.5 & 19.7 & 22.2 & 7.8 & 23.8 & 8.7 & 25.2 & 9.7 & 26.9 & 10.5 \\
\hline Tape recorder & 57.2 & 57.6 & 57.2 & 47.9 & 21.6 & 48.9 & 20.7 & 47.9 & 20.4 & 48.6 & 18.7 \\
\hline Refrigerator & 73.0 & 76.1 & 77.7 & 80.1 & 12.3 & 81.9 & 13.6 & 87.4 & 14.8 & 88.7 & 15.9 \\
\hline Automobile & 0.2 & 0.3 & 0.3 & 0.5 & & 0.6 & & 0.9 & & 1.4 & \\
\hline
\end{tabular}

Source: China Statistical Yearbook 1998-2004. 
Comparing the available statistics of PC ownership by income in urban areas (see Table 8) shows income is a decisive factor in PC penetration.

Table 8. PC ownership by income level (units per 100 households)

\begin{tabular}{|l|r|r|r|r|}
\hline & $\mathbf{1 9 9 8}$ & $\mathbf{1 9 9 9}$ & $\mathbf{2 0 0 1}$ & $\mathbf{2 0 0 2}$ \\
\hline Difficult households & 0.9 & 1.6 & 3.9 & 2.1 \\
\hline Lowest income households & 1.3 & 1.8 & 3.2 & 2.8 \\
\hline Low income households & 1.7 & 2.1 & 6.3 & 5.5 \\
\hline Lower middle income households & 2.4 & 3.7 & 8.5 & 10.7 \\
\hline Middle income households & 3.6 & 5.7 & 12.5 & 17.8 \\
\hline Upper middle income households & 4.0 & 7.2 & 16.5 & 28.1 \\
\hline High income households & 5.9 & 10.1 & 22.1 & 37.2 \\
\hline Highest income households & 8.8 & 12.0 & 26.0 & 53.8 \\
\hline Source: Statistical Yearbook 1999- 2003.
\end{tabular}

Another divide that is striking is the regional divide. The PC ownership rate is much higher in Beijing, Shanghai and Guangdong than in other districts/provinces/regions, and is very low in the so-called Western provinces. There are signs of improvement however, as the province with the lowest penetration rate in 2002, Qinghai (see Figure 6), has a penetration level comparable to the rate of the fourth province in 1998, that is after the cities of Beijing and Shanghai and the province of Guangdong (see Figure 5).

Figure 5. PC ownership by region, end 1998 (units per 100 households)

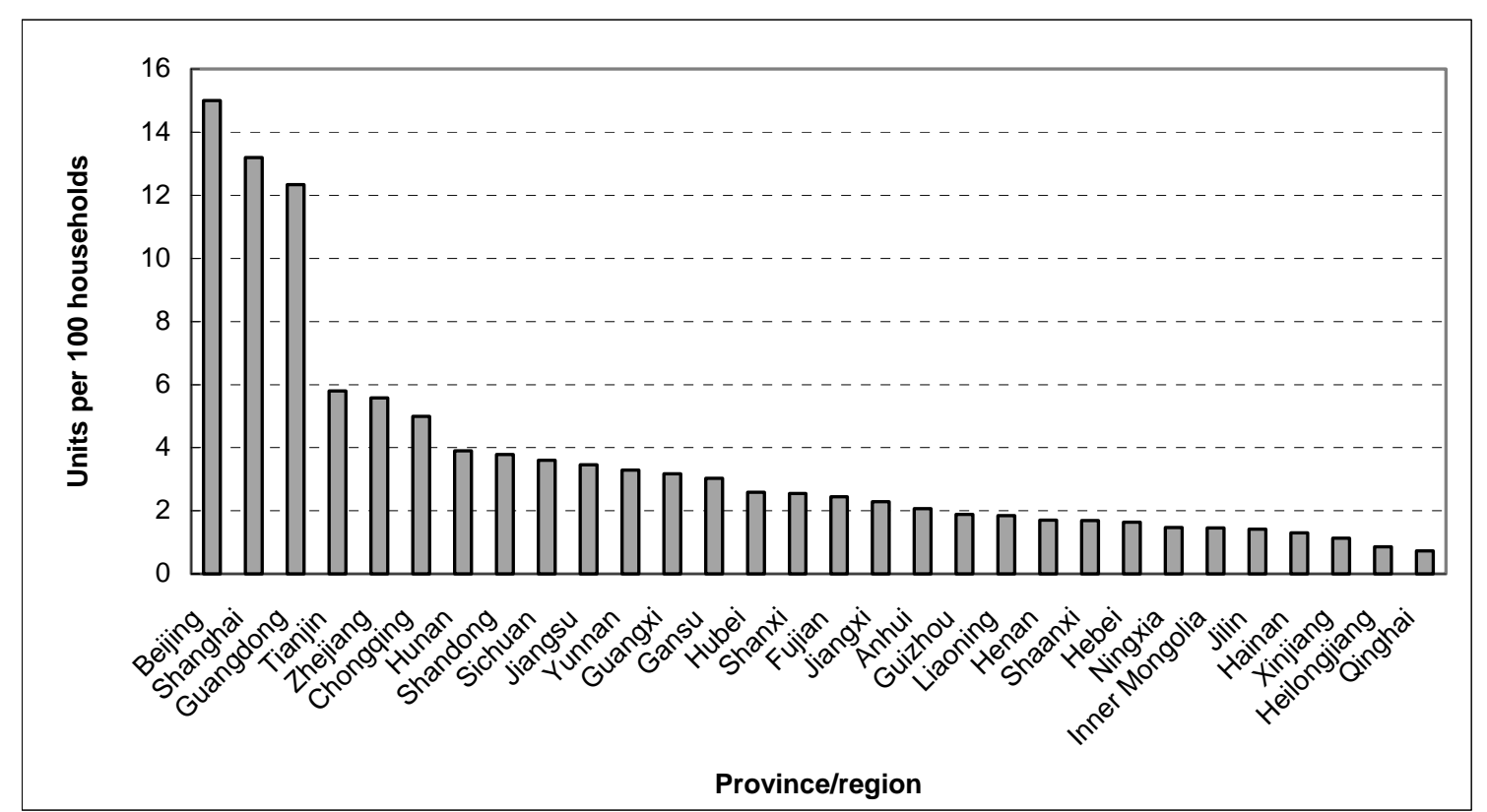

Source: China Statistical Yearbook 1999. 
Figure 6. PC ownership by region, end 2002 (units per 100 households)

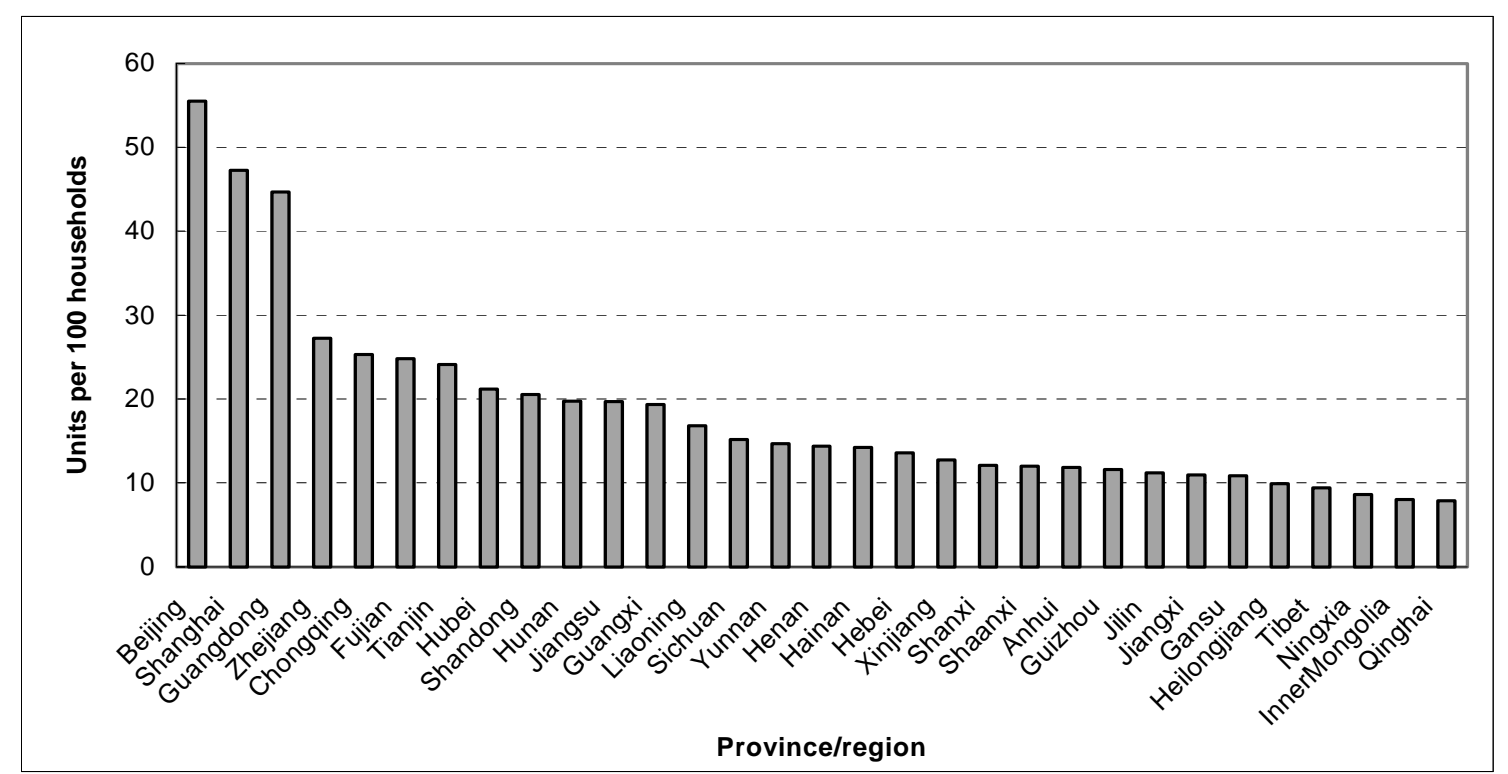

Source: China Statistical Yearbook 2003.

\section{Internet penetration - the digital divide in China}

Internet penetration and Internet usage by individuals in China are captured through surveys that are conducted by the China Internet Network Information Center (CNNIC). The survey takes the form of reporting from the Internet Service Providers, as well as through on-line and off-line surveys that are delegated to ISPs by CNNIC. The number of individuals surveyed varies greatly from survey to survey, contributing to the uncertainty regarding the accuracy of the statistics. The characteristics of the surveys can be found in Table 9 .

Table 9. Survey characteristics

\begin{tabular}{|l|c|c|c|c|}
\hline & \multicolumn{2}{|c|}{ On-line surveys } & \multicolumn{2}{c|}{ Off-line surveys } \\
\hline & Number of responses & Of which valid & Telephone survey & Interview \\
\hline Oct-97 & & 1802 & & \\
\hline Jun-98 & 3098 & 2494 & & \\
\hline Dec-98 & 23876 & 22177 & & \\
\hline Jun-99 & 66283 & 52549 & & \\
\hline Dec-99 & 363538 & 202432 & & 3679 \\
\hline Jun-00 & 1629361 & 573902 & & 6000 \\
\hline Dec-00 & 34695 & 26667 & 62620 & \\
\hline Jun-01 & 144083 & 78342 & 5828 & \\
\hline Dec-01 & 75383 & 64627 & &.. \\
\hline Jun-02 &.. &.. & 49600 &.. \\
\hline Dec-02 & 39456 & 29948 & 4800 &.. \\
\hline Jun-03 & 72767 & 19096 & 49600 &.. \\
\hline Dec-03 & 49653 & 16760 & 7200 & \\
\hline Jun-04 & 23624 & 17833 & 49600 & \\
\hline Dec-04 & 32143 & 23506 & & \\
\hline Souc-: & & & & \\
\hline
\end{tabular}

Source: Statistical reports of the development of China Internet (October 1997 - January 2005). 
Statistics on the number of Web sites in China are directly collected by CNNIC, as it is the only entity at present which is allowed to assign ".cn" domain names. Figure 7 reports a sudden increase between June 2000 and December of that year, since when the number of Web sites was stable at first, increasing steadily since June 2002. The cause for the sudden increase is undocumented in the statistical reports from which the numbers are drawn, however the data for December 1998 to June 2000 indicate, in fine print, "estimated".

Figure 7. Estimated number of Web sites in China (1 000s)

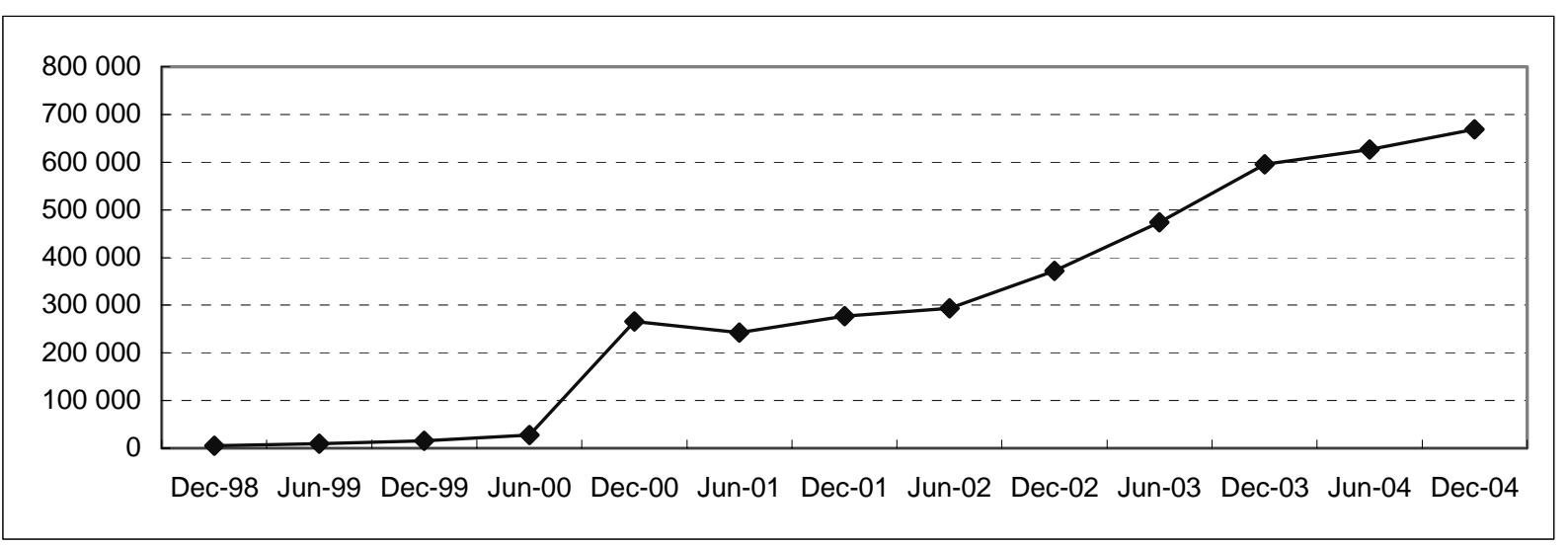

Note: including gTLDs that are registered in China and .cn domains.

Source: Statistical reports of the development of China Internet (January 1999 - January 2005).

As with the number of Web sites, domain name registrations have been stable for the period from December 2000 to June 2002, after which the numbers have increased, as shown in Table 10. The biggest growth between June 2002 and December 2002 can be attributed to the increase in ".com.cn" domains which showed a $35 \%$ growth, and is the single largest category of domain names, hovering constantly at around $80 \%$ of the total domain names registered, until second level domain names were introduced into the statistics.

Table 10. Number of ".cn” domain names

\begin{tabular}{|l|r|r|r|r|r|r|r|r|r|r|r|r|}
\hline & Dec98 & Jun99 & Dec99 & Dec00 & Jun01 & Dec01 & Jun02 & Dec02 & Jun03 & Dec03 & Jun04 & Dec04 \\
\hline SLD & & & & & & & & & 94469 & 158072 & 176782 & 193869 \\
\hline com.cn & 13913 & 22220 & 38776 & 96221 & 99922 & 99123 & 98835 & 133796 & 120957 & 140779 & 158293 & 173649 \\
\hline net.cn & 1223 & 2221 & 3753 & 13291 & 15055 & 14045 & 12248 & 20234 & 13957 & 16189 & 18374 & 20145 \\
\hline gov.cn & 982 & 1663 & 2479 & 4615 & 5181 & 5864 & 6686 & 7796 & 9328 & 11764 & 13963 & 16326 \\
\hline AADN & 906 & 1175 & 1516 & 3567 & 3434 & 3317 & 3172 & 4774 & 3109 & 3286 & 3702 & 15765 \\
\hline org.cn & 409 & 649 & 940 & 2596 & 2864 & 2943 & 3031 & 9587 & 6342 & 7369 & 8351 & 9415 \\
\hline edu.cn & 531 & 615 & 731 & 1127 & 1239 & 1354 & 1482 & 1629 & 1787 & 1915 & 2073 & 2226 \\
\hline ac.cn & 432 & 502 & 500 & 682 & 667 & 673 & 692 & 1728 & 702 & 666 & 678 & 682 \\
\hline Total & $\mathbf{1 8 3 9 6}$ & $\mathbf{2 9 0 4 5}$ & $\mathbf{4 8 6 9 5}$ & $\mathbf{1 2 2 0 9 9}$ & $\mathbf{1 2 8 3 6 2}$ & $\mathbf{1 2 7 3 1 9}$ & $\mathbf{1 2 6 1 4 6}$ & $\mathbf{1 7 9 5 4 4}$ & $\mathbf{2 5 0 6 5 1}$ & $\mathbf{3 4 0 0 4 0}$ & $\mathbf{3 8 2 2 1 6}$ & $\mathbf{4 3 2 0 7 7}$ \\
\hline
\end{tabular}

Note: AADN = Administration Area Domain Name; SLD = Second Level Domain Name.

Source: Statistical reports of the development of China Internet (January 1999 - January 2005).

The geographical distribution of Chinese domain names shows a concentration in the municipalities of Beijing and Shanghai and the Eastern Coastal region of Guangdong, which together had a share of about $60 \%$ until 2002, dropping to under 50\% in 2003 (see Table 11). The share of the Western region has remained low at about $7-8 \%$. 
Table 11. Geographical distribution of “.cn” domain names (\%)

\begin{tabular}{|c|c|c|c|c|c|c|c|c|c|c|}
\hline & Jun-99 & Dec-99 & Jun-00 & Dec-00 & Jun-01 & Dec-01 & Jun-02 & Dec-02 & Jun-03 & Dec-03 \\
\hline \multicolumn{11}{|l|}{ Municipalities } \\
\hline Beijing & 36.7 & 36.7 & 38.2 & 36.9 & 34.8 & 33.8 & 31.0 & 33.4 & 23.0 & 24.9 \\
\hline Shanghai & 7.7 & 8.9 & 8.6 & 9.2 & 9.4 & 9.8 & 10.5 & 8.7 & 9.2 & 8.5 \\
\hline Tianjin & 1.8 & 1.8 & 1.6 & 1.7 & 1.7 & 1.7 & 1.7 & 1.4 & 1.6 & 1.6 \\
\hline Chongqing & 0.9 & 0.8 & 1.0 & 0.9 & 0.9 & 0.9 & 1.0 & 0.9 & 1.1 & 1.1 \\
\hline Subtotal & 47.1 & 48.2 & 49.4 & 48.7 & 46.8 & 46.2 & 44.2 & 44.4 & 34.9 & 36.1 \\
\hline \multicolumn{11}{|c|}{ Eastern Coastal Region } \\
\hline Guangdong & 15.0 & 14.5 & 13.9 & 14.1 & 14.1 & 14.7 & 15.9 & 13.9 & 14.1 & 14.0 \\
\hline Fujian & 2.4 & 2.5 & 2.4 & 2.5 & 2.4 & 2.5 & 2.5 & 2.2 & 2.8 & 3.4 \\
\hline Zhejiang & 3.9 & 4.4 & 4.1 & 4.0 & 4.3 & 4.4 & 4.6 & 3.9 & 5.5 & 5.8 \\
\hline Jiangsu & 5.1 & 4.9 & 4.3 & 4.5 & 5.2 & 5.4 & 5.3 & 5.0 & 5.7 & 6.1 \\
\hline Subtotal & 26.4 & 26.2 & 24.7 & 25.1 & 26.0 & 27.0 & 28.3 & 24.9 & 28.1 & 29.3 \\
\hline \multicolumn{11}{|l|}{ Western Region } \\
\hline Inner Mongolia & 0.5 & 0.5 & 0.4 & 0.5 & 0.5 & 0.5 & 0.5 & 0.5 & 0.7 & 0.6 \\
\hline Guangxi & 1.2 & 1.0 & 0.8 & 0.7 & 0.7 & 0.8 & 0.8 & 0.8 & 0.9 & 0.8 \\
\hline Sichuan & 2.1 & 1.5 & 1.5 & 1.8 & 1.9 & 1.9 & 1.9 & 1.6 & 2.0 & 2.2 \\
\hline Guizhou & 0.3 & 0.3 & 0.2 & 0.3 & 0.3 & 0.3 & 0.3 & 0.3 & 0.4 & 0.4 \\
\hline Yunnan & 0.9 & 1.6 & 1.4 & 1.4 & 1.3 & 1.2 & 1.1 & 0.8 & 0.9 & 1.0 \\
\hline Tibet & 0.0 & 0.0 & 0.1 & 0.1 & 0.1 & 0.1 & 0.1 & 0.2 & 0.2 & 0.2 \\
\hline Shaanxi & 1.5 & 1.5 & 1.3 & 1.3 & 1.4 & 1.4 & 1.4 & 2.0 & 1.1 & 1.2 \\
\hline Gansu & 0.4 & 0.4 & 0.3 & 0.3 & 0.4 & 0.4 & 0.4 & 0.3 & 0.4 & 0.4 \\
\hline Qinghai & 0.0 & 0.0 & 0.1 & 0.1 & 0.1 & 0.1 & 0.1 & 0.1 & 0.1 & 0.1 \\
\hline Ningxia & 0.1 & 0.1 & 0.2 & 0.3 & 0.3 & 0.3 & 0.3 & 0.3 & 0.3 & 0.3 \\
\hline Xinjiang & 0.3 & 0.4 & 0.7 & 0.9 & 0.9 & 0.9 & 0.9 & 0.8 & 1.0 & 0.8 \\
\hline Subtotal & 7.1 & 7.2 & 7.0 & 7.6 & 7.9 & 7.9 & 7.8 & 7.7 & 8.0 & 8.0 \\
\hline \multicolumn{11}{|l|}{ Other provinces } \\
\hline Hebei & 1.9 & 1.8 & 1.7 & 1.7 & 1.8 & 1.9 & 2.1 & 1.9 & 2.0 & 1.8 \\
\hline Shanxi & 0.5 & 0.6 & 0.7 & 0.6 & 0.7 & 0.7 & 0.7 & 0.6 & 0.5 & 0.5 \\
\hline Shandong & 4.9 & 4.8 & 4.2 & 3.9 & 3.9 & 3.9 & 4.0 & 3.3 & 3.8 & 4.0 \\
\hline Anhui & 0.8 & 0.7 & 0.7 & 0.9 & 1.0 & 1.0 & 1.1 & 1.0 & 1.2 & 1.1 \\
\hline Liaoning & 2.8 & 2.6 & 2.4 & 3.1 & 3.4 & 2.9 & 2.9 & 2.6 & 2.9 & 2.9 \\
\hline Jilin & 0.7 & 0.6 & 0.7 & 0.6 & 0.7 & 0.7 & 0.7 & 0.7 & 1.2 & 1.1 \\
\hline Heilongjiang & 0.8 & 0.9 & 0.9 & 1.0 & 1.0 & 1.0 & 1.1 & 0.9 & 1.1 & 1.0 \\
\hline Jiangxi & 0.5 & 0.4 & 0.4 & 0.4 & 0.4 & 0.4 & 0.5 & 0.5 & 0.7 & 0.7 \\
\hline Henan & 2.7 & 2.3 & 2.0 & 1.6 & 1.6 & 1.6 & 1.7 & 1.4 & 1.5 & 1.4 \\
\hline Hubei & 2.1 & 1.8 & 1.7 & 1.7 & 1.8 & 1.8 & 1.9 & 3.1 & 1.8 & 1.8 \\
\hline Hunan & 0.9 & 0.9 & 0.9 & 0.9 & 1.0 & 1.0 & 1.0 & 0.8 & 1.0 & 0.9 \\
\hline Hainan & 1.1 & 0.7 & 1.8 & 1.1 & 0.8 & 0.7 & 0.7 & 0.4 & 0.4 & 0.3 \\
\hline Subtotal & 19.4 & 18.2 & 18.0 & 17.5 & 18.1 & 17.6 & 18.4 & 17.3 & 18.1 & 17.5 \\
\hline \multicolumn{11}{|c|}{ Special Administrative Districts } \\
\hline Hong Kong, China & 0.1 & 0.2 & 1.0 & 1.2 & 1.2 & 1.3 & 1.3 & 1.0 & & \\
\hline Macao & & 0.0 & 0.0 & 0.0 & & & & & & \\
\hline Subtotal & 0.1 & 0.2 & 1.0 & 1.2 & 1.2 & 1.3 & 1.3 & 1.0 & 0.0 & \\
\hline Chinese Taipei & & 0.0 & 0.0 & 0.0 & & & & 0.0 & & \\
\hline Overseas & & & & & & & & 4.8 & 10.9 & 9.1 \\
\hline
\end{tabular}

Note: Excluding .edu.cn domain names.

Source: Statistical reports of the development of China Internet (July 1999 - January 2004). 
Internet penetration can be measured by the number of PCs connected to the Internet and by the number of Internet users, which are reported in Table 12. The rates of increase for both indicators do not show any sign of slowing down. The number of broadband connections has been growing rapidly in the last three years.

Table 12. Internet penetration in China (1 000s)

\begin{tabular}{|l|r|r|r|r|r|r|r|r|r|r|r|}
\hline & Dec98 & Jun99 & Dec99 & Dec00 & Dec01 & Jun02 & Dec02 & Jun03 & Dec03 & Jun04 & Dec04 \\
\hline $\begin{array}{l}\text { PCs connected } \\
\text { to the Internet }\end{array}$ & 747 & 1460 & 3500 & 8920 & 12540 & 16130 & 20830 & 25720 & 30890 & 36300 & 41600 \\
\hline - leased line & 117 & 250 & 410 & 1410 & 2340 & 3070 & 4030 & 5150 & 5950 & 6520 & 7000 \\
\hline - dial-up & 630 & 1210 & 3090 & 7510 & 10200 & 12000 & 14800 & 17390 & 19450 & 20970 & 21400 \\
\hline - others & & & & & & 1060 & 2000 & 3180 & 5490 & 8810 & 13200 \\
\hline Internet users & 2100 & 4000 & 8900 & 22500 & 33700 & 45800 & 59100 & 68000 & 79500 & 87000 & 94000 \\
\hline - leased-line & 400 & 400 & 1090 & 3640 & 6720 & 9460 & 20230 & 23420 & 26600 & 28700 & 30500 \\
\hline - dial-up & 1490 & 2560 & 6660 & 15430 & 21330 & 26820 & 40800 & 45010 & 49160 & 51550 & 52400 \\
\hline - ISDN & & & & & & 3150 & 4320 & 4900 & 5520 & 6000 & 6400 \\
\hline - broadband & & & & & & 2000 & 6600 & 9800 & 17400 & 31100 & 42800 \\
\hline - - ther means & & & 200 & 920 & & & & & & & \\
\hline
\end{tabular}

Notes: Access through other means includes access through mobile phones, PDA, set-top boxes; Internet users who adopt multiple access methods are counted double, therefore the sum of the different categories exceeds the total.

Source: Statistical reports of the development of China Internet (January 1999 - January 2005).

The gender breakdown of Internet users in China - as shown in Figure 8 - has been balancing out from $86 \%$ to $14 \%$ in December 1998 to $61 \%$ to $39 \%$ in June 2001, and has remained almost stable since then.

Figure 8. Gender breakdown of Internet users in China (\%)

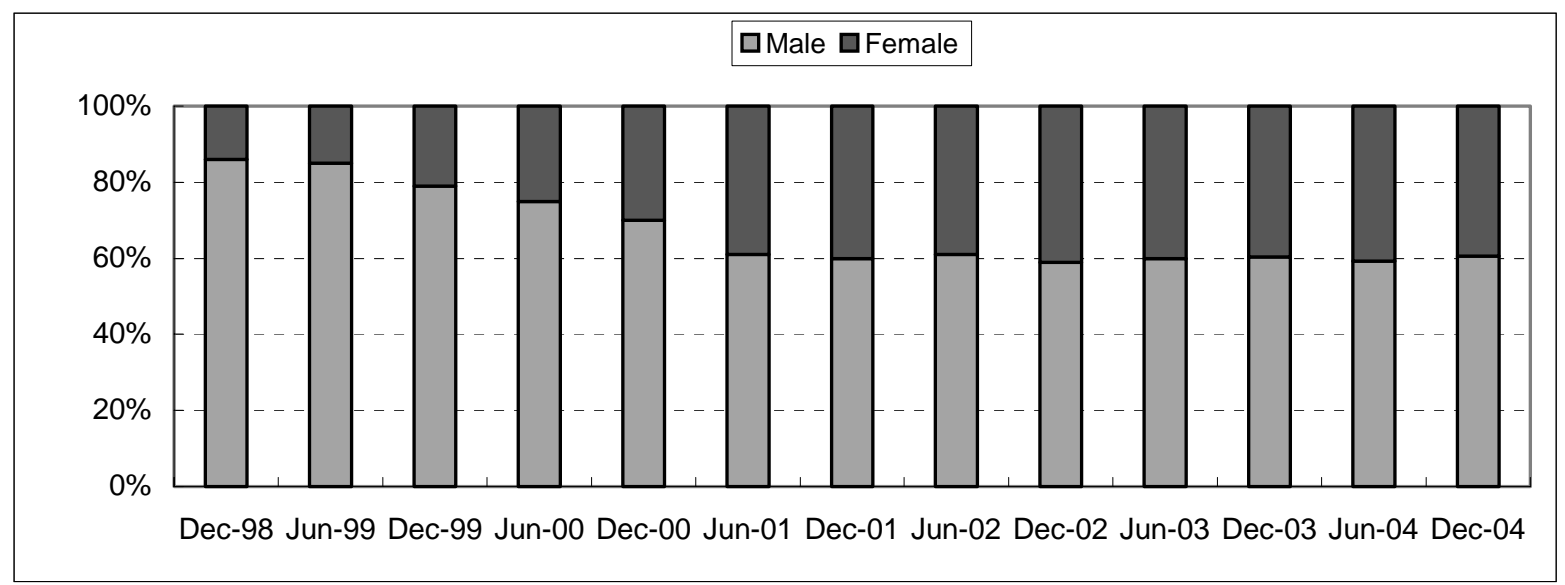

Source: Statistical reports of the development of China Internet (January 1999 - January 2005). 


\section{DSTI/DOC(2005)4}

The age profile of Chinese Internet users has not changed drastically over time, except for the 25-30 age segment, which peaked at 32.8\% in the December 1999 survey (see Table 13) and has gone down as low as $16.1 \%$ in June 2001. The population belonging to the age segment under 35 has a share of over $80 \%$ of Internet users, down from $88.2 \%$ in the December 1999 survey.

Table 13. Age profile of Chinese Internet users

\begin{tabular}{|l|r|r|r|r|r|r|r|r|r|r|r|}
\hline & \multicolumn{1}{|c|}{ Dec-99 } & \multicolumn{1}{|c|}{ Jun-00 } & Dec-00 & \multicolumn{1}{|c|}{ Jun-01 } & Dec-01 & Jun-02 & Dec-02 & Jun-03 & Dec-03 & Jun-04 & Dec-04 \\
\hline Under 24 & 45.2 & 48.4 & 56.1 & 51.9 & 51.5 & 53.3 & 54.9 & 56.2 & 52.9 & 54.1 & 51.7 \\
\hline $25-30$ & 32.8 & 29.2 & 18.8 & 16.1 & 16.3 & 16.9 & 17.0 & 17.2 & 17.2 & 16.4 & 17.7 \\
\hline $31-35$ & 10.2 & 10.0 & 8.9 & 11.8 & 12.1 & 11.6 & 10.2 & 10.3 & 12.1 & 11.5 & 11.4 \\
\hline $36-40$ & 5.7 & 5.6 & 7.1 & 8.3 & 8.2 & 7.2 & 7.4 & 7.4 & 7.6 & 7.3 & 7.6 \\
\hline $41-50$ & 4.5 & 5.1 & 5.7 & 8.0 & 7.6 & 6.8 & 6.8 & 6.0 & 6.4 & 6.7 & 7.6 \\
\hline Over 50 & 1.6 & 1.7 & 3.3 & 3.9 & 4.3 & 4.0 & 3.7 & 2.9 & 3.8 & 4.0 & 4.0 \\
\hline
\end{tabular}

Source: Statistical reports of the development of China Internet (January 2000 - January 2005).

The education profile in Table 14 indicates that there is a rapid increase of the share of people with a lower education profile (high school and less), from 14\% in the June 1999 survey to $42.3 \%$ four and a half years later. One would conjecture from this an increase in Internet penetration in schools, where children are most likely to get acquainted with the Internet. In addition, part of this increase could be associated with the rise in the content that could attract people with a lower age profile (such as network games and other content of an entertainment nature), who may not have been attracted to traditional content on the Internet, such as news and other information.

Table 14. Educational profile of Chinese Internet users (\%)

\begin{tabular}{|l|r|r|r|r|r|r|r|r|r|r|r|}
\hline & Jun99 & Jun00 & Dec00 & Jun01 & Dec01 & Jun02 & Dec02 & Jun03 & Dec03 & Jun04 & Dec04 \\
\hline < high school & 2.0 & 2.5 & 6.4 & 8.7 & 10.2 & 11.5 & 12.9 & 13.9 & 13.5 & 12.6 & 13.0 \\
\hline High school & 12.0 & 12.8 & 23.5 & 28.8 & 30.0 & 30.5 & 30.6 & 30.9 & 23.9 & 30.6 & 29.3 \\
\hline Junior college & 27.0 & 32.8 & 29.0 & 26.7 & 26.9 & 26.3 & 26.1 & 27.1 & 27.4 & 26.0 & 27.0 \\
\hline Bachelor & 48.0 & 45.9 & 38.8 & 33.6 & 30.4 & 29.2 & 27.6 & 25.5 & 27.1 & 28.2 & 27.6 \\
\hline Master & 9.0 & 4.9 & 1.9 & 1.8 & 2.1 & 2.1 & 2.3 & 2.1 & 2.2 & 2.1 & 2.7 \\
\hline Doctorate & 2.0 & 1.0 & 0.4 & 0.4 & 0.4 & 0.4 & 0.5 & 0.5 & 0.5 & 0.5 & 0.4 \\
\hline
\end{tabular}

Source: Statistical reports of the development of China Internet (July 1999 - January 2005). 
There has been a rapid increase in the share of Internet users belonging to lower income profiles among Internet users, especially in the category under CNY 500, which went up from 7\% in the December 1999 survey to $40 \%$ by the June 2003 survey, after which it decreased to $34.2 \%$ in December 2004 (see Table 15). The breakdown has stabilised somewhat since the December 2000 survey, with those with income lower than the average wage in Beijing, CNY 2000 , hovering around 80\%. In absolute terms, the number of Internet users with an income of less than CNY 2000 has increased from 6.4 million in December 1999 to 75.8 million in December 2004 (an annual average growth of 63.9\%), whereas the number of those with income above CNY 2000 increased from 2.5 million to 18.2 million in the same period (an annual average growth of $48.9 \%$ ).

Table 15. Income profile of Chinese Internet users (\%) based on monthly income (in CNY)

\begin{tabular}{|c|c|c|c|c|c|c|c|c|c|c|c|}
\hline & Dec-99 & Jun-00 & Dec-00 & Jun-01 & Dec-01 & Jun-02 & Dec-02 & Jun-03 & Dec-03 & Jun-04 & Dec-04 \\
\hline No income & \multirow{2}{*}{7.0} & \multirow{2}{*}{8.3} & 16.3 & 13.3 & 12.3 & 13.0 & 16.5 & 19.5 & 10.4 & 11.3 & 6.2 \\
\hline Under 500 & & & 15.3 & 20.0 & 23.6 & 24.8 & 23.5 & 20.8 & 23.8 & 27.7 & 28.0 \\
\hline $501-1000$ & 29.0 & 28.2 & 25.9 & 25.5 & 25.3 & 24.1 & 20.9 & 18.3 & 15.6 & 16.3 & 19.0 \\
\hline $1001-1500$ & \multirow{2}{*}{36.0} & \multirow{2}{*}{37.8} & 15.8 & 16.3 & 16.5 & 16.5 & 15.4 & 15.9 & 16.5 & 13.2 & 16.7 \\
\hline $1501-2000$ & & & 7.5 & 9.3 & 8.8 & 8.2 & 8.2 & 9.8 & 11.3 & 9.6 & 10.7 \\
\hline 2001 - 2500 & \multirow{3}{*}{19.0} & \multirow{3}{*}{18.5} & 4.3 & 5.6 & 4.4 & 4.6 & 5.1 & 4.6 & 6.2 & 6.2 & 5.3 \\
\hline $2501-3000$ & & & 3.5 & 3.7 & 3.4 & 2.6 & 3.8 & 3.7 & 5.7 & 6.4 & 5.4 \\
\hline $3001-4000$ & & & 2.9 & 3.1 & 2.3 & 2.7 & 3.1 & 2.4 & 4.9 & 4.4 & 3.6 \\
\hline $4001-5000$ & \multirow{2}{*}{5.0} & \multirow{2}{*}{4.5} & 1.8 & 1.4 & 1.1 & 1.3 & 1.3 & 2.0 & 2.4 & 1.7 & 2.2 \\
\hline $5001-6000$ & & & 1.6 & 0.5 & 0.8 & 0.7 & 0.7 & 0.9 & 1.2 & 1.3 & 1.0 \\
\hline $6001-10000$ & \multirow{2}{*}{4.0} & \multirow{2}{*}{2.9} & 0.5 & 0.5 & 0.7 & 0.6 & 0.7 & 1.0 & 1.1 & 1.1 & 1.1 \\
\hline Above 10000 & & & 0.6 & 1.1 & 0.5 & 0.9 & 0.8 & 1.1 & 0.9 & 0.8 & 0.8 \\
\hline Not sure & & & 4.0 & & & & & & & & \\
\hline
\end{tabular}

Notes: In 2002, the average monthly wage in Beijing was around CNY 2000 for a civil servant; CNY 5000 - 6000 for a Japanese company and CNY 8000 or more for a European/North American based company.

Source: Statistical reports of the development of China Internet (January 2000 - January 2005). 


\section{DSTI/DOC(2005)4}

The trend in the geographical profile that emerges from Table 16, is a decrease in the share of Internet users in the municipalities of Beijing and Shanghai (from 28.2\% in December 1998 to $10.4 \%$ in 2003) as well as the Eastern Coastal province of Guangdong (from $20.9 \%$ to $12.0 \%$ during the same period), with an increase in share of the Western Region (from 10.9\% to 18.7\%). There is a trend towards resolving the regional digital divide in terms of Internet users.

Table 16. Geographical profile of Chinese Internet users (\%)

\begin{tabular}{|c|c|c|c|c|c|c|c|c|}
\hline & Dec-98 & Jun-99 & Dec-99 & Jun-00 & Dec-00 & Dec-01 & Dec-02 & Dec-03 \\
\hline \multicolumn{9}{|l|}{ Municipalities } \\
\hline Beijing & 23.9 & 21.0 & 21.2 & 18.7 & 12.4 & 9.8 & 6.6 & 5.0 \\
\hline Shanghai & 4.3 & 8.7 & 11.2 & 10.8 & 9.0 & 9.2 & 7.1 & 5.4 \\
\hline Tianjin & 1.7 & 2.1 & 2.7 & 2.8 & 2.5 & 2.7 & 2.3 & 1.8 \\
\hline Chongqing & 1.5 & 1.5 & 1.9 & 1.8 & 2.0 & 1.6 & 2.5 & 2.2 \\
\hline Subtotal & 31.4 & 33.3 & 37.0 & 34.1 & 25.9 & 23.3 & 18.5 & 14.4 \\
\hline \multicolumn{9}{|c|}{ Eastern Coastal Area } \\
\hline Guangdong & 20.9 & 11.8 & 12.9 & 12.8 & 9.7 & 10.4 & 9.5 & 12.0 \\
\hline Fujian & 3.1 & 3.7 & 2.7 & 1.9 & 3.6 & 3.6 & 3.8 & 4.0 \\
\hline Zhejiang & 4.6 & 6.0 & 4.5 & 4.9 & 6.6 & 6.6 & 5.5 & 5.7 \\
\hline Jiangsu & 5.3 & 6.8 & 5.9 & 6.8 & 5.4 & 8.0 & 8.1 & 7.7 \\
\hline Subtotal & 33.9 & 28.3 & 26.0 & 26.4 & 25.3 & 28.6 & 26.9 & 29.4 \\
\hline \multicolumn{9}{|l|}{ Western Region } \\
\hline Inner Mongolia & 0.4 & 0.7 & 0.5 & 0.4 & 1.2 & 1.2 & 1.2 & 1.0 \\
\hline Guangxi & 2.0 & 1.6 & 1.3 & 0.9 & 2.0 & 2.6 & 2.0 & 2.9 \\
\hline Sichuan & 3.5 & 5.1 & 3.0 & 3.4 & 5.0 & 5.2 & 5.2 & 5.3 \\
\hline Guizhou & 0.5 & 0.3 & 0.5 & 0.4 & 0.8 & 0.6 & 0.8 & 1.1 \\
\hline Yunnan & 0.4 & 1.0 & 0.6 & 0.7 & 1.5 & 1.5 & 1.7 & 2.1 \\
\hline Tibet & 0.0 & 0.0 & 0.0 & 0.0 & 0.0 & 0.1 & 0.1 & 0.1 \\
\hline Shaanxi & 2.4 & 2.8 & 2.0 & 2.8 & 1.5 & 1.5 & 2.2 & 2.5 \\
\hline Gansu & 0.6 & 0.7 & 0.6 & 0.6 & 1.1 & 1.3 & 1.2 & 1.5 \\
\hline Qinghai & 0.1 & 0.1 & 0.1 & 0.1 & 0.3 & 0.2 & 0.3 & 0.3 \\
\hline Ningxia & 0.3 & 0.2 & 0.2 & 0.2 & 0.5 & 0.3 & 0.3 & 0.4 \\
\hline Xinjiang & 0.7 & 0.9 & 0.5 & 0.6 & 1.5 & 1.3 & 1.4 & 1.5 \\
\hline Subtotal & 10.9 & 13.4 & 9.3 & 10.1 & 15.4 & 15.8 & 16.4 & 18.7 \\
\hline \multicolumn{9}{|l|}{ Other provinces } \\
\hline Hebei & 1.7 & 2.1 & 2.6 & 2.2 & 2.5 & 2.8 & 3.7 & 3.6 \\
\hline Shanxi & 1.0 & 0.9 & 1.0 & 1.0 & 1.3 & 1.2 & 1.6 & 1.9 \\
\hline Liaoning & 3.6 & 3.4 & 4.3 & 3.3 & 4.7 & 3.8 & 4.8 & 3.7 \\
\hline Jilin & 1.1 & 1.1 & 1.5 & 1.4 & 2.4 & 1.8 & 2.4 & 1.8 \\
\hline Heilongjiang & 2.1 & 2.2 & 1.7 & 1.7 & 2.5 & 2.8 & 3.8 & 2.8 \\
\hline Anhui & 1.4 & 1.5 & 1.0 & 1.2 & 2.4 & 2.5 & 1.9 & 2.3 \\
\hline Jianxi & 1.7 & 1.2 & 1.1 & 0.9 & 2.1 & 1.8 & 2.0 & 2.1 \\
\hline Shangdong & 3.7 & 4.2 & 5.2 & 8.5 & 5.3 & 4.3 & 6.5 & 7.9 \\
\hline Henan & 2.1 & 1.5 & 2.1 & 2.2 & 2.3 & 3.1 & 2.8 & 2.8 \\
\hline Hubei & 3.3 & 3.7 & 3.3 & 4.6 & 3.5 & 4.3 & 5.4 & 4.8 \\
\hline Hunan & 1.7 & 2.2 & 3.4 & 2.1 & 4.0 & 3.4 & 2.9 & 3.3 \\
\hline Hainan & 0.5 & 0.4 & 0.5 & 0.3 & 0.3 & 0.5 & 0.4 & 0.5 \\
\hline Subtotal & 23.9 & 24.4 & 27.7 & 29.4 & 33.3 & 32.3 & 38.2 & 37.5 \\
\hline
\end{tabular}

Source: Statistical reports of the development of China Internet (January 1999 - January 2004). 


\section{ICT usage and electronic commerce}

Because the survey on the point of access to the Internet allows multiple replies, almost all indicators show an increase over time or remain more or less constant (see Table 17). However, the most striking aspect is the increase of those who connect at home, which increased from 58.8\% in June 2000 to $67.9 \%$ in December 2004. Measurement of access through mobile appliances started in June 2002, but access through mobile phones and other mobile devices such as PDAs still remains limited, although it showed a relatively sharp increase in 2004.

Table 17. Point of access to the Internet (\%)

\begin{tabular}{|l|r|r|r|r|r|r|r|r|r|r|}
\hline & Jun-00 & Dec-00 & Jun-01 & Dec-01 & Jun-02 & Dec-02 & Jun-03 & Dec-03 & Jun-04 & Dec-04 \\
\hline Home & 58.8 & 60.3 & 61.0 & 61.3 & 62.1 & 62.6 & 65.9 & 66.1 & 67.0 & 67.9 \\
\hline Office & 43.0 & 43.9 & 45.1 & 45.7 & 43.3 & 42.5 & 43.0 & 43.6 & 42.7 & 41.1 \\
\hline School & & 20.6 & 18.3 & 19.7 & 21.8 & 20.2 & 22.6 & 18.4 & 20.6 & 18.2 \\
\hline Internet café & 20.9 & 19.7 & 15.2 & 15.4 & 17.3 & 19.4 & 18.1 & 20.3 & 22.0 & 24.5 \\
\hline Public library & & & & & 0.7 & 0.6 & 0.4 & 0.5 & 1.8 & 0.4 \\
\hline Mobile access & & & & & 0.9 & 0.5 & 0.5 & 0.6 & 2.2 & 2.1 \\
\hline Others & 8.8 & 4.1 & 0.2 & 0.7 & 0.5 & 0.4 & 0.7 & 0.1 & 0.1 & 0.5 \\
\hline
\end{tabular}

Note: Multiple replies allowed.

Source: Statistical reports of the development of China Internet (July 2000 - January 2005).

Figure 9 shows that time spent on the Internet has been decreasing between December 1999 (17 hours) and June 2001 (8.7 hours). The fact that with the increased penetration of Internet, non-core users started to use the Internet could have contributed to this decrease. Since June 2001, the average time spent has flattened out at around 8-9 hours per week until the June 2002 survey, going up to 13.2 hours in December 2004.

Figure 9. Time spent on the Internet (hours per week)

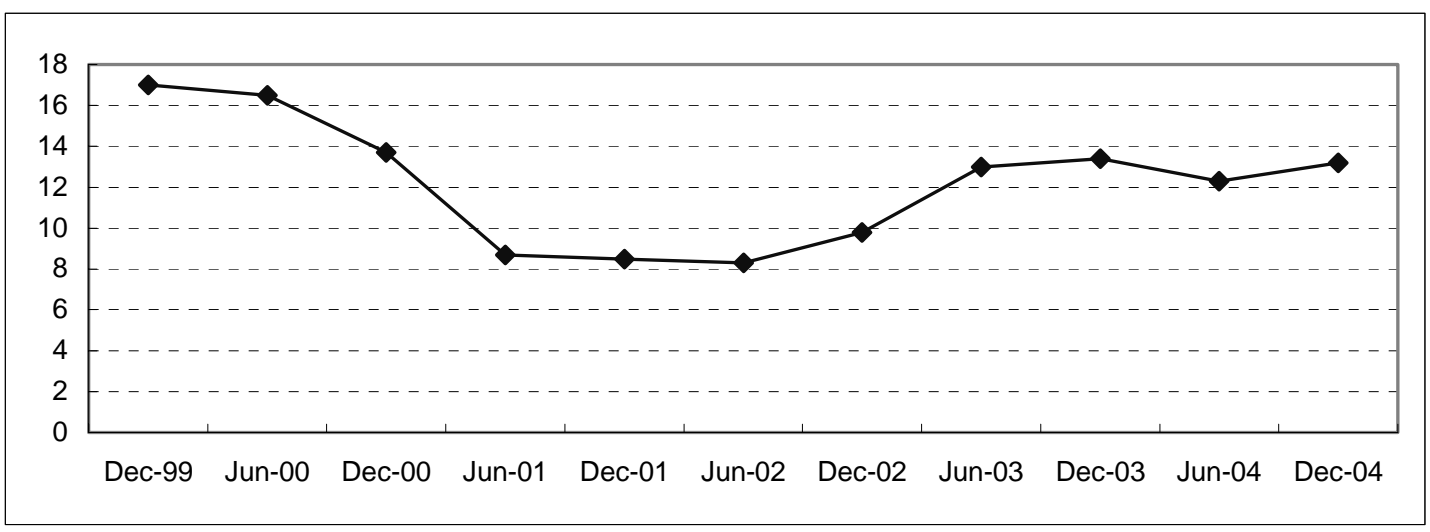

Source: Statistical reports of the development of China Internet (January 2000 - January 2005). 


\section{DSTI/DOC(2005)4}

Table 18 shows the primary objectives of Internet use. The top reason has constantly been to "get information including news". Entertainment, which includes chatting, making friends (separated since the June 2002 survey) and playing games were the most important use of the Internet for $35.7 \%$ of users in December 2004. As mentioned before, the development of entertainment content could be contributing to the increase in users with a lower educational background.

Table 18. Primary objective of Internet use (\%)

\begin{tabular}{|l|r|r|r|r|r|r|r|r|r|r|}
\hline & Dec99 & Jun00 & Jun01 & Dec01 & Jun02 & Dec02 & Jun03 & Dec03 & Jun04 & Dec04 \\
\hline Get information - including news & 58.0 & 56.1 & 42.9 & 46.1 & 47.6 & 53.1 & 46.9 & 46.2 & 42.3 & 39.1 \\
\hline Entertainment $\left(^{*}\right)$ & 6.8 & 10.8 & 34.4 & 31.1 & 18.9 & 24.6 & 28.6 & 32.2 & 34.5 & 35.7 \\
\hline Education $\left.{ }^{* *}\right)$ & 12.1 & 10.9 & 4.3 & 4.3 & 7.4 & 5.8 & 7.6 & 8.4 & 10.2 & 8.8 \\
\hline Making friends & & & & & 14.9 & 7.0 & 7.5 & 4.4 & 5.5 & 6.2 \\
\hline Get free Internet resources $\left(^{* * * \star}\right)$ & 5.5 & 6.4 & 3.1 & 3.3 & 1.2 & 1.9 & 1.7 & 1.8 & 2.7 & 2.5 \\
\hline Communication $\left(^{* \star \star}\right)$ & 5.1 & 4.1 & 4.1 & 4.9 & 4.4 & 3.8 & 3.2 & 2.7 & 1.8 & 1.7 \\
\hline Stock trading and information retrieval & 1.1 & 2.5 & 4.1 & 2.5 & 0.9 & 1.1 & 2.1 & 1.5 & 1.0 & 1.2 \\
\hline Business activities & 9.8 & 7.0 & 5.8 & 6.2 & 0.8 & 1.0 & 0.4 & 0.3 & 0.2 & 0.3 \\
\hline Jumping on the bandwagon & 0.2 & 0.3 & 0.5 & 0.6 & 0.3 & 0.3 & 0.6 & 0.3 & 0.4 & 0.2 \\
\hline On-line purchasing & & & 0.3 & 0.4 & 0.3 & 0.1 & 0.2 & 0.1 & 0.3 & 0.1 \\
\hline For sentimental needs & & & & & 1.2 & 1.1 & 0.1 & 0.8 & 0.9 & 1.1 \\
\hline Saving/reducing communication costs & 1.1 & 1.2 & & & & & & & & \\
\hline Others & 0.4 & 0.7 & 0.5 & 0.6 & 2.1 & 0.2 & 1.1 & 1.3 & 0.2 & 3.1 \\
\hline Total & $\mathbf{1 0 0}$ & $\mathbf{1 0 0}$ & $\mathbf{1 0 0}$ & $\mathbf{1 0 0}$ & $\mathbf{1 0 0}$ & $\mathbf{1 0 0}$ & $\mathbf{1 0 0}$ & $\mathbf{1 0 0}$ & $\mathbf{1 0 0}$ & $\mathbf{1 0 0}$ \\
\hline
\end{tabular}

* Entertainment: on-line chatting, making friends, playing games, etc.

** Education: study; learning computer and other new technologies.

*** Communication: receive/send e-mails, short messages; send faxes, etc.

${ }^{* * * *}$ Free Internet resources: e-mail account, personal homepage hosting, resources download services.

Source: Statistical reports of the development of China Internet (January 2000 - January 2005). 
The primary objective of Internet use, "to get information including news", is reflected in the information searched on the Internet (see Table 19). "News" has consistently attracted the highest proportion of votes, followed by "hardware and software" and "entertainment" (the second objective of Internet use).

Table 19. Information searched on the Internet (\%)

\begin{tabular}{|c|c|c|c|c|c|c|c|c|c|}
\hline & Jun99 & Dec99 & Dec00 & Dec01 & Jun02 & Dec02 & Jun03 & Dec03 & Dec04 \\
\hline News & 84 & 65.5 & 84.4 & 74.0 & 75.8 & 78.0 & 76.9 & 70.9 & 74.2 \\
\hline Hardware and software & 68 & 51.7 & 58.0 & 55.6 & 60.3 & 53.4 & 47.6 & 44.7 & 49.2 \\
\hline Entertainment & 47 & 38.8 & 52.7 & 46.5 & 41.3 & 44.6 & 44.9 & 41.7 & 44.6 \\
\hline Living services & & & & 27.8 & 24.9 & 27.8 & 32.1 & 34.1 & 42.3 \\
\hline E-books & 52 & 38.0 & 46.0 & 37.4 & 35.6 & 32.6 & 31.5 & 28.8 & 36.7 \\
\hline Science and technology & & & & & & & & 18.9 & 29.3 \\
\hline Science and education & 41 & 31.4 & 35.8 & 31.8 & 28.8 & 30.1 & 28.2 & 22.9 & 26.5 \\
\hline Social culture & & & & 20.4 & 14.8 & 17.9 & 19.0 & 18.2 & 26.5 \\
\hline Job hunting & 21 & 19.3 & 29.1 & 22.2 & 19.0 & 22.1 & 20.3 & 20.5 & 24.2 \\
\hline Prize awarding activities & & & & & & & & 17.6 & 20.2 \\
\hline Sports & & & & & 21.2 & 20.4 & 16.9 & 12.8 & 19.3 \\
\hline Military information & & & & & & & & 8.1 & 15.5 \\
\hline Law, regulation and policy & & & & 13.7 & 8.3 & 8.5 & 8.2 & 7.7 & 15.1 \\
\hline Enterprise information & & & & & 5.3 & 6.5 & 6.9 & 9.1 & 14.7 \\
\hline Travel and transportation & 14 & 11.9 & 12.6 & 11.4 & 7.3 & 7.6 & 6.7 & 7.5 & 14.6 \\
\hline Automobile information & & & & & 8.4 & 8.0 & 9.6 & 7.4 & 13.8 \\
\hline Finance and insurance & 26 & 21.2 & 22.9 & 16.4 & 11.8 & 11.0 & 10.2 & 8.5 & 12.1 \\
\hline Business and trade & 19 & 17.3 & 15.7 & 9.9 & 6.7 & 7.5 & 7.5 & 8.4 & 12.1 \\
\hline Weather forecast & & & & & 5.0 & 7.2 & 7.5 & & \\
\hline Medical care & 10 & 9.4 & 11.8 & 7.7 & 4.9 & 4.9 & 5.6 & 5.7 & 11.3 \\
\hline Real estate & & & & & 3.9 & 4.6 & 4.9 & 4.7 & 9.4 \\
\hline E-government & & & & & 2.5 & 3.1 & 3.5 & 3.6 & 7.5 \\
\hline Advertisements & 14 & 12.8 & 13.5 & 6.4 & 5.1 & 5.8 & 5.6 & 3.8 & 5.4 \\
\hline Matchmaking & 9 & 8.2 & 9.3 & 4.5 & 2.8 & 2.9 & 2.6 & 1.9 & 2.9 \\
\hline Others & 2 & 0.7 & 13.3 & 1.6 & 0.8 & 0.7 & 0.8 & 0.8 & 11.3 \\
\hline
\end{tabular}

Note: Multiple replies allowed.

Source: Statistical reports of the development of China Internet (July 1999 - January 2005). 


\section{DSTI/DOC(2005)4}

Table 20 shows the Internet services that are most frequently used by ranking the use of various individual Internet media. While the categories somewhat overlap with each other, e-mail, search engines, news, information gathering, on-line chatting and software download and upload constantly rank high.

Table 20. Internet services most frequently used (\%)

\begin{tabular}{|c|c|c|c|c|c|c|c|c|c|c|}
\hline & Jun99 & Dec99 & Dec00 & Jun01 & Dec01 & Jun02 & Dec02 & Jun03 & Dec03 & Dec04 \\
\hline E-mail & 90.0 & 71.7 & 95.1 & 74.9 & 92.2 & 92.9 & 92.6 & 91.8 & 88.4 & 85.6 \\
\hline Search engines & 65.5 & 50.4 & 66.8 & 51.3 & 62.7 & 63.8 & 68.3 & 70.0 & 61.6 & 65.0 \\
\hline News & & & & & & & & & 59.2 & 62.0 \\
\hline Information gathering & 54.8 & 39.3 & 44.7 & 39.5 & 46.7 & 40.3 & 42.2 & 37.8 & 47.2 & 49.9 \\
\hline On-line chatting & 29.2 & 25.5 & 37.5 & 21.9 & 22.0 & 45.5 & 45.4 & 45.4 & 39.1 & 42.6 \\
\hline Software download / upload & 59.6 & 44.2 & 50.6 & 43.9 & 55.3 & 51.0 & 45.3 & 43.0 & 38.7 & 37.4 \\
\hline BBS Community forum & 28.0 & 16.3 & 16.7 & 9.0 & 9.8 & 18.9 & 18.9 & 22.6 & 18.8 & 20.8 \\
\hline Newsgroup & 21.4 & 17.0 & 19.3 & 10.7 & 13.4 & & 21.3 & 20.7 & & \\
\hline On-line games & 15.8 & 13.6 & 18.9 & 15.8 & & 18.6 & 18.1 & 18.2 & 14.7 & 15.9 \\
\hline School/classmate BBS & & & & & & & & & 15.7 & 14.8 \\
\hline Multimedia (mp3, flash etc.) & & & & & 22.1 & 19.7 & 13.4 & 13.0 & 7.8 & 8.0 \\
\hline E-magazine & & & & & & 11.2 & 9.5 & 8.2 & 3.9 & 7.3 \\
\hline On-line purchasing & 3.2 & 7.8 & 12.5 & 8.0 & 7.8 & 10.3 & 11.5 & 11.7 & 7.3 & 6.7 \\
\hline On-line education & & & & 11.8 & 11.8 & 8.9 & 8.9 & 8.9 & 6.2 & 6.3 \\
\hline On-line banking & & & & & & 2.8 & 3.6 & 4.3 & 4.5 & 5.1 \\
\hline Free Web site hosting & 21.6 & 13.5 & 15.6 & 8.4 & 11.8 & 8.6 & 6.8 & 6.2 & 5.0 & 4.9 \\
\hline Video on demand & & & & & & 5.2 & 5.6 & 5.3 & 3.5 & 3.9 \\
\hline Recruitment on-line & & & & & & & & & 4.7 & 3.5 \\
\hline $\begin{array}{l}\text { On-line stock trading } \\
\text { and information }\end{array}$ & 9.7 & 8.5 & 10.9 & 10.3 & 7.4 & 7.1 & 5.5 & 5.4 & 3.7 & 3.4 \\
\hline Short messages & & & & & 8.0 & 8.8 & 8.8 & 7.8 & 3.8 & 2.3 \\
\hline Information dissemination & & & & & & & 4.2 & 4.4 & 2.0 & 2.3 \\
\hline Live broadcast & & & & & & 4.4 & 3.6 & 3.7 & 2.2 & 2.2 \\
\hline E-government & & & & & & 1.4 & 1.9 & 2.1 & 2.0 & 2.0 \\
\hline On-line sales & & & & & & & 1.2 & 1.3 & 1.2 & 1.6 \\
\hline On-line promotion & & & & & & & & & 0.9 & 1.3 \\
\hline VolP & & & & & 1.7 & 1.0 & 1.0 & 1.0 & 0.8 & 1.0 \\
\hline Internet database & & & & & & & & & 0.9 & 0.8 \\
\hline On-line auctions & & & & & & 0.7 & 0.9 & 1.1 & 0.8 & 0.7 \\
\hline Telnet & & & & & & & 1.1 & 1.2 & 0.6 & 0.7 \\
\hline $\begin{array}{l}\text { Informationisation } \\
\text { (ERP, CRM, SCM) }\end{array}$ & & & & & & 0.2 & 1.2 & 1.1 & 0.8 & 0.6 \\
\hline On-line hospitals & & & & & & 0.8 & 0.7 & 0.8 & 0.5 & 0.6 \\
\hline On-line ticket/hotel reservations & & & & & & 0.7 & 0.8 & 0.5 & 0.4 & 0.5 \\
\hline On-line video conferences & & & & & & 0.3 & 0.3 & 0.5 & 0.4 & 0.4 \\
\hline On-line pagers & 14.8 & 13.2 & 24.6 & 31.6 & 37.6 & & & & & \\
\hline
\end{tabular}

Note: Multiple replies allowed.

Source: Statistical reports of the development of China Internet (July 1999 - January 2005). 
Despite the low level of importance attributed to being able to carry out electronic commerce, about one third of Internet users surveyed have carried out B2C electronic commerce since the December 2000 survey, up to $40 \%$ in December 2004 (see Figure 10). ${ }^{12}$

Figure 10. Proportion of Internet users buying goods/services on-line during the past year (\%)

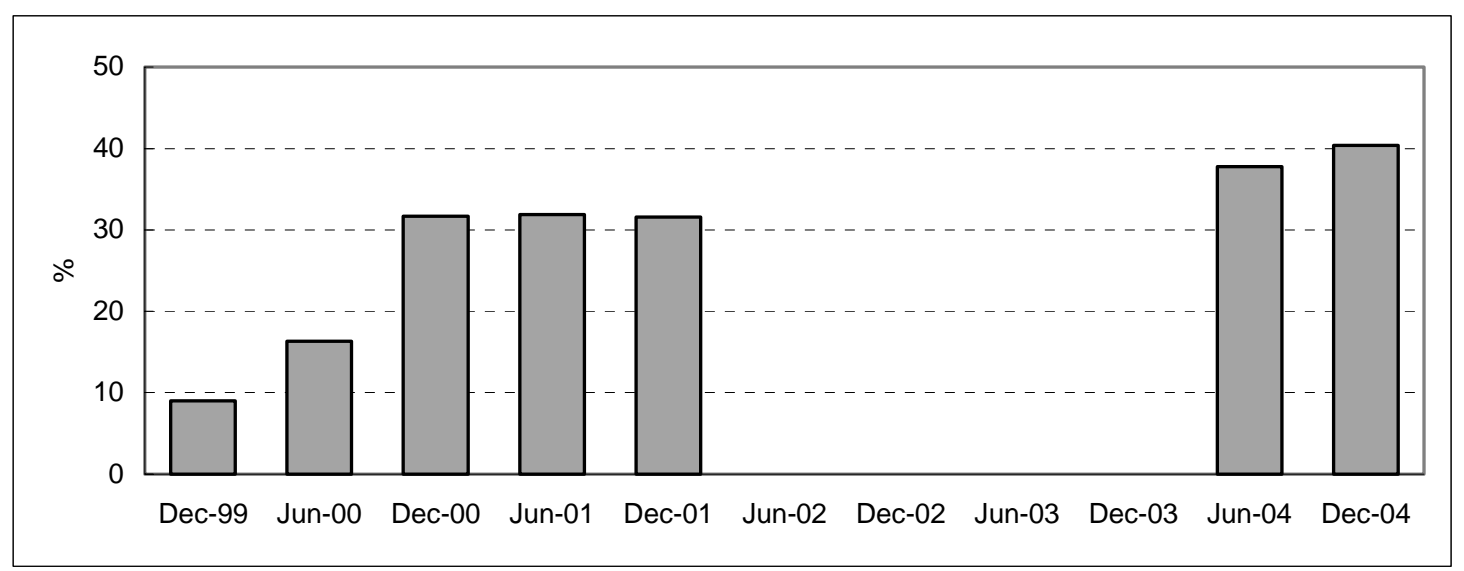

Note: Since the December 2000 survey, this question has been formulated as "Have you ever purchased goods or services through online shopping Web sites in the most recent 12 months?". In 2002 and 2003 the question was "Have you ever purchased goods or services through online shopping Web sites?"

Source: Statistical reports of the development of China Internet (January 2000 - January 2005).

12. This figure is very high compared with that of OECD countries. A possible explanation could be that the question "Have you ever purchased goods or services through online shopping Web sites in the most recent 12 months" was misunderstood by respondents as "Have you ever purchased goods or services through online shopping Web sites?". Alternatively, the question may have been phrased differently, and was translated incorrectly into English. 


\section{DSTI/DOC(2005)4}

Table 21 reports that in December 2004 almost 60\% of those engaged in e-commerce had bought books in the 12 months preceding the survey. About one-third had bought computer appliances.

Table 21. Goods bought through the Internet during the last 12 months (\%)

\begin{tabular}{|l|r|r|r|r|r|r|r|r|}
\hline & Jun00 & Dec00 & Dec01 & Jun02 & Dec02 & Jun03 & Dec03 & Dec04 \\
\hline Books and magazines & 45.1 & 58.3 & 58.0 & 69.0 & 67.7 & 63.8 & 61.7 & 58.8 \\
\hline Computer appliances & 37.2 & 37.5 & 33.7 & 33.2 & 29.9 & 30.7 & 32.4 & 34.2 \\
\hline Audio-visual equipment and products & 15.6 & 29.1 & 34.4 & 38.3 & 34.9 & 31.4 & 27.9 & 23.9 \\
\hline Living and housing services & 12.1 & 14.3 & 11.6 & 11.6 & 11.0 & 13.5 & 12.6 & 16.5 \\
\hline Communication appliances & 17.1 & 19.9 & 15.5 & 11.6 & 12.5 & 12.5 & 13.9 & 13.7 \\
\hline Products related to Internet games & & & & & & & & 12.8 \\
\hline Gift services & 11.2 & 16.4 & 14.7 & 12.1 & 12.7 & 11.8 & 12.3 & 12.7 \\
\hline Clothing & 7.7 & 6.9 & 4.4 & 5.0 & 5.5 & 7.8 & 9.4 & 10.1 \\
\hline Photographic equipment & 7.5 & 4.9 & 3.6 & 4.3 & 6.2 & 7.7 & 9.0 & 9.5 \\
\hline Family electrical appliances & 9.4 & 8.4 & 5.6 & 7.3 & 7.1 & 8.0 & 6.3 & 8.9 \\
\hline Cosmetics & & & & & & & 6.4 & 7.5 \\
\hline Educational services & 10.2 & 13.1 & 11.8 & 9.5 & 9.8 & 9.6 & 8.6 & 6.2 \\
\hline Sports equipment & 7.0 & 6.9 & 4.4 & 5.4 & 4.7 & 5.4 & 6.3 & 5.9 \\
\hline Tickets & 9.6 & 8.5 & 9.7 & 7.9 & 7.7 & 4.6 & 6.6 & 5.2 \\
\hline Office appliances & & & & & & & 3.1 & 3.5 \\
\hline Hotel reservations & & & & 5.2 & 4.3 & 3.8 & 3.4 & 3.1 \\
\hline Medical care services & 4.9 & 4.4 & 3.1 & 3.0 & 2.7 & 3.7 & 3.1 & 2.8 \\
\hline Financial and insurance services & 4.6 & 3.8 & 2.6 & 2.5 & 2.1 & 2.3 & 2.3 & 1.9 \\
\hline Food & & & & & & & 1.6 & 1.2 \\
\hline Others & 11.1 & 9.0 & 3.1 & 1.8 & 2.3 & 2.0 & 2.4 & 1.4 \\
\hline Nor Mulip reples
\end{tabular}

Note: Multiple replies allowed.

Source: Statistical reports of the development of China Internet (July 2000 - January 2005).

Asked why people are hesitant to buy on line, $42.4 \%$ of the people sampled in December 2004 had doubts about the quality of the product they wished to buy (see Table 22). This barrier has gained importance, as security fears and inconvenient payment modes have become less important, although the importance of security fears has been rising again since the July 2002 survey.

Table 22. Barriers to purchasing on line (\%)

\begin{tabular}{|l|r|r|r|r|r|r|r|r|r|r|}
\hline & Jun99 & Dec99 & Dec00 & Jun01 & Dec01 & Jun02 & Dec02 & Jun03 & Dec03 & Dec04 \\
\hline Product quality not guaranteed & 34 & 36.5 & 32.0 & 33.0 & 30.2 & 36.9 & 39.3 & 40.0 & 42.1 & 42.4 \\
\hline Security not guaranteed & 30 & 27.6 & 31.2 & 33.4 & 31.0 & 22.1 & 23.4 & 25.1 & 28.1 & 34.3 \\
\hline Unreliable information & & & 5.9 & 6.0 & 6.3 & 5.9 & 6.4 & 7.0 & 6.7 & 7.3 \\
\hline Late delivery & 6 & 9.3 & 9.9 & 8.7 & 13.9 & 10.2 & 8.6 & 7.1 & 7.5 & 5.3 \\
\hline Unattractive price & 8 & 7.8 & 7.4 & 6.6 & 6.3 & 11.1 & 10.8 & 10.3 & 7.5 & 5.2 \\
\hline Inconvenient payment mode & 22 & 17.7 & 12.6 & 11.5 & 11.8 & 13.0 & 10.8 & 9.9 & 7.4 & 5.1 \\
\hline Others & & 1.1 & 1.0 & 0.8 & 0.5 & 0.8 & 0.7 & 0.6 & 0.7 & 0.4 \\
\hline
\end{tabular}

Source: Statistical reports of the development of China Internet (July 1999 - January 2005). 


\section{Conclusion}

In this document an attempt has first been made to list the main sources from which official ICT statistics for China can be compiled. The conclusion can be drawn that there is a fair amount of data on infrastructure and on Internet usage by individuals, as well as some supply-side data.

These data show that China is a major assembly factory for ICT goods. They also show that ICTs and the Internet are rapidly becoming very important in China, although there is a large digital divide inside the country in terms of income, and especially in terms of regional discrepancies.

Firm level data of Internet usage, including data on electronic commerce is either not collected or not publicly disclosed. This is an area where assistance could be provided in formulating questionnaires and surveys to government bodies in charge of collecting such statistics (presumably the Ministry of Information Industry).

ICT penetration in schools is also an area that can be envisaged for future work, but the extent of the usefulness of such surveys is questionable in view of the fact that the provision of basic education is still an issue to be solved in certain parts of China.

Studying official ICT statistics in China as a whole, and comparing them to those of OECD member countries, is somewhat questionable, in view of the wide discrepancy of development within China. Urban and rural areas have obvious developmental discrepancies. Within urban areas, there is also a discrepancy between the Eastern Coastal area and the so-called Western Region.

In view of this situation, further studies could limit their focus onto China's developed Coastal areas (Guangdong, Fujian, Zhejiang and Jiangsu) and the Municipalities of Beijing, Tianjin, Shanghai and Chongqing. Obtaining official statistics from those provinces and municipalities might pose additional difficulties, however, as contacts would need to be made with individual local governments.

Additional further work would include the need to adapt these statistics to international norms such as those developed by the OECD and its member countries. 


\section{BIBLIOGRAPHY}

China Internet Network Information Center, Semi-annual Survey Report on the Development of China's Internet, various issues.

Maruyama, Tomoo (ed.) (2000), Handbook of Chinese Industries 2001-2002, Sososha, Tokyo.

Mitsubishi Research Institute (2000), Handbook of Information on China 2000, Sososha, Tokyo.

National Bureau of Statistics (various years), China Statistical Yearbook, Beijing.

OECD (Organisation for Economic Co-operation and Development) (2003), "A proposed classification of ICT goods", Working Party on Indicators for the Information Society,

DSTI/ICCP/IIS(2003)1/REV2, http://www.oecd.org/dataoecd/5/61/22343094.pdf.

Sanwa Research Institute (2001), Asia's IT Revolution, Toyo Keizai Shimpohsha, Tokyo. 


\section{ANNEX 1: DEFINITIONS ${ }^{13}$}

Economically Active Population refers to the population aged 16 and over who are capable of working, are participating in or willing to participate in economic activities, including employed persons and unemployed persons.

Employed Persons refers to persons who are engaged in social labour and receive remuneration payment or earn business income, including total staff and workers, re-employed retirees, employers of private enterprises, self-employed workers, employees in private enterprises and individual economy, employees in township enterprises, employed persons in rural areas, other employed persons (including teachers in schools run by local people, people engaged in religious profession, etc.). This indicator reflects the actual utilisation of the total labour force during a certain period of time and is often used for research on China's economic situation and national power.

Staff and Workers refers to persons who work in (and receive payment from) enterprises and institutions under state ownership, collective ownership, joint ownership, share holding, foreign ownership and ownership by entrepreneurs from Macao, Chinese Taipei and Hong Kong, China and other types of ownership and their affiliated units, excluding the retired persons invited to work in the units again, teachers in the schools run by local people and foreigners and persons coming from Macao, Chinese Taipei and Hong Kong, China and working in state-owned economic units. Numbers of staff and workers in the yearbook include only fully employed staff and workers, excluding those who have left their working units while keeping their labour contract/employment relation unchanged.

Total Wages of Staff and Workers refers to the total remuneration payment to staff and workers in various units during a certain period of time. The calculation of total wages is based on total remuneration payment to staff and workers. Therefore, all wages and salaries and other payments to staff and workers are included in total wages, regardless of their sources, category and forms (in kind or cash). Total wages of staff and workers in the yearbook include only total wages of fully employed staff and workers, excluding living allowances distributed to those who have left their working units while keeping their labour contract/employment relation unchanged.

Average Wage of Staff and Workers refers to the average wage in money terms per person during a certain period of time for staff and workers in enterprises, institutions and government agencies, which reflects the general level of wage income during a certain period of time and is calculated as follows:

Average Wage of Staff and Workers=Total Wages of Staff and Workers in Reference Period / Average Number of Staff and Workers in Reference Period

Subscribers of Paging Services refers to subscribers who carry small-size pagers and receive audio signals, digital signals or character signals sent out by a city telephone through a wireless paging centre within an assigned area. Each pager is counted as a subscriber.

13. Source: National Bureau of Statistics. 
Mobile Telephone Subscribers refers to those who own a mobile telephone number connected with the mobile telephone communication network and registered by the post and telecommunications organisation. Subscribers are counted only when they have gone through all the registration formalities and are entered into the mobile telephone network. One mobile telephone is treated as a subscriber.

Since 1997, the classification of telephone subscribers and number of telephones was modified on the basis of the physical location of the subscribers as "urban telephone subscribers" and "rural telephone subscribers", which is different from the previous classification of categorising "local telephones" and "rural telephones", while the definitions of total subscribers and total number of telephones remain unchanged.

1. Urban telephone subscribers refers to telephone subscribers connected to exchanges installed in the urban and suburban districts of cities under the jurisdiction of central and provincial governments, of cities at prefecture or county levels and in county towns (including towns where the county government is located). They also include subscribers connected to exchanges installed in independent industrial and mining zones, forest zones and military institutions located in rural areas.

2. Rural telephone subscribers refers to telephone subscribers connected to exchanges installed in small towns and in rural areas.

3. Household telephone subscribers refers to telephone sets installed in the dwelling units of residents and include three types of payment for the service: private payment, public payment and free service.

4. Private-paid telephone subscribers refers to subscribers who pay for the installation and service of telephones. 


\section{ANNEX 2: ICT PRODUCT CLASSIFICATION USED BY THE CHINESE MINISTRY OF INFORMATION INDUSTRY}

The manufacturing sectors covered by the Ministry of Information Industry are:

- Telecommunication equipment

- Broadcasting equipment

- Computer equipment and software (see detailed list below)

- Household electronics

- Electronic measuring instruments

- Electronic devices

- Electronics parts and equipment

- Materials for the production of electronics

Table 23 shows a list of computer related products used by the Ministry of Information Industry.

Table 23. Computer-related products

\begin{tabular}{|c|c|c|}
\hline \multirow{4}{*}{ Main Frame } & Large and Medium & \\
\hline & Small & \\
\hline & Workstation & IA-based \\
\hline & & RISC-based \\
\hline \multirow[t]{14}{*}{ Personal Computer } & Desktop & Business-use \\
\hline & & Home-use \\
\hline & Server & \\
\hline & Portable PC & Laptop \\
\hline & & Palm devices \\
\hline & & Windows CE devices \\
\hline & Network Appliances & Hub and Concentrator \\
\hline & & Router \\
\hline & & Exchanger \\
\hline & & Modem \\
\hline & & Bridge \\
\hline & & Gateway \\
\hline & & Firewall \\
\hline & & Other Network devices \\
\hline \multirow[t]{8}{*}{ PC Peripherals } & Floppy Disk Drives & Normal floppy \\
\hline & & Large capacity floppy \\
\hline & Hard Disk Drive & HDD \\
\hline & & HD array \\
\hline & Optical Drive & CD-ROM \\
\hline & & CD-R \\
\hline & & CD-RW \\
\hline & & DVD-ROM \\
\hline
\end{tabular}




\begin{tabular}{|c|c|c|}
\hline & & DVD-RW \\
\hline & & $\mathrm{MO}$ \\
\hline & & PD \\
\hline & & Other \\
\hline & Display device & Character Display Terminal \\
\hline & & Graphical Display Terminal \\
\hline & & Computer Display \\
\hline & & Black and White CRT Display \\
\hline & & Colour CRT Display \\
\hline & & LCD Display \\
\hline & & Other \\
\hline & Printer & Dot Matrix \\
\hline & & 24-pin Printer \\
\hline & & Form Printer \\
\hline & & Line Printer \\
\hline & & Laser Printer \\
\hline & & Inkjet Printer \\
\hline PC parts & Cards & Motherboard \\
\hline & & Memory module \\
\hline & & Sound card \\
\hline & & Display card \\
\hline & & Network Interface Card \\
\hline & Power Supply Units & Normal Power Supply \\
\hline & & UPS units \\
\hline & Other parts & PC case \\
\hline & & Hard disk plates \\
\hline & & Floppy disks \\
\hline & & Optical disks \\
\hline & & Printer head \\
\hline & & Magnetic card \\
\hline & & Printer ink \\
\hline & & IC cards \\
\hline Software & Operating System-related software & Operating System \\
\hline & & Database Systems \\
\hline & & Network Systems \\
\hline & & Chinese Character Processing Systems \\
\hline & & Graphics Management Systems \\
\hline & & Human Interface Systems \\
\hline & & Others \\
\hline & Intermediate Software & Intermediate Software \\
\hline & & Security Software \\
\hline & & Virus Protection \\
\hline & & Data Compression \\
\hline & & Network Security \\
\hline & & Authentication, Authorisation and Audit software \\
\hline & & Other security software \\
\hline & Application Software & Business-oriented Chinese Language processing \\
\hline & & Financial Software \\
\hline & & Enterprise management \\
\hline & & Business management \\
\hline & & Other management software \\
\hline & & Translation software \\
\hline & & Education software \\
\hline & & Games and entertainment \\
\hline & & Electronic publishing \\
\hline & & $\mathrm{CAD} / \mathrm{CAM}$ \\
\hline & & Geographic Information Systems \\
\hline & & Other \\
\hline
\end{tabular}

